Brief Report

\title{
Transcriptional Profile of Cytokines, Regulatory Mediators and TLR in Mesenchymal Stromal Cells after Inflammatory Signaling and Cell-Passaging
}

\author{
Makram Merimi ${ }^{1,2,+}$, Karolien Buyl ${ }^{3,+}$, Dhouha Daassi ${ }^{4}$, Robim M. Rodrigues ${ }^{3}$, Rahma Melki ${ }^{2}$, \\ Philippe Lewalle ${ }^{1}$, Tamara Vanhaecke ${ }^{3}$, Hassan Fahmi ${ }^{5}$, Vera Rogiers ${ }^{3}$, Laurence Lagneaux ${ }^{6}$, Joery De Kock ${ }^{3} \mathbb{D}$ \\ and Mehdi Najar $5,6, *, \neq$ (iD
}

Citation: Merimi, M.; Buyl, K.;

Daassi, D.; Rodrigues, R.M.; Melki, R.; Lewalle, P.; Vanhaecke, T.; Fahmi, H.;

Rogiers, V.; Lagneaux, L.; et al. Transcriptional Profile of Cytokines, Regulatory Mediators and TLR in Mesenchymal Stromal Cells after Inflammatory Signaling and Cell-Passaging. Int. J. Mol. Sci. 2021 22, 7309. https://doi.org/10.3390/ ijms22147309

Academic Editor: Katia Mareschi

Received: 10 May 2021

Accepted: 24 June 2021

Published: 7 July 2021

Publisher's Note: MDPI stays neutral with regard to jurisdictional claims in published maps and institutional affiliations.

Copyright: (c) 2021 by the authors Licensee MDPI, Basel, Switzerland. This article is an open access article distributed under the terms and conditions of the Creative Commons Attribution (CC BY) license (https:// creativecommons.org/licenses/by/ $4.0 /)$
1 Department of Hematology, Laboratory of Experimental Hematology, Institut Jules Bordet, Université Libre de Bruxelles (ULB), 1000 Bruxelles, Belgium; makram.merimi.cri@gmail.com (M.M.); philippe.lewalle@bordet.be (P.L.)

2 Genetics and Immune Cell Therapy Unit, Faculty of Sciences, University Mohammed Premier, Oujda 60000, Morocco; r.melki@ump.ac.ma

3 Department of In Vitro Toxicology and Dermato-Cosmetology (IVTD), Faculty of Medicine and Pharmacy, Vrije Universiteit Brussel (VUB), Laarbeeklaan 103, 1090 Brussels, Belgium; Karolien.Buyl@vub.be (K.B.); rmarceli@vub.ac.be (R.M.R.); Tamara.Vanhaecke@vub.be (T.V.); vrogiers@vub.ac.be (V.R.); Joery.De.Kock@vub.be (J.D.K.)

4 Department of Neurology, Icahn School of Medicine at Mount Sinai, New York, NY 10029-5674, USA; bioengdhouha@gmail.com

5 Osteoarthritis Research Unit, Centre Hospitalier de l’Université de Montréal, University of Montreal Hospital Research Center (CRCHUM), Montreal, QC H2X 0A9, Canada; h.fahmi@umontreal.ca (H.F.)

6 Laboratory of Clinical Cell Therapy, Institut Jules Bordet, Université Libre de Bruxelles (ULB), 1070 Brussels, Belgium; laurence.lagneaux@bordet.be

* Correspondence: mnajar@ulb.ac.be

+ Co-first authors.

$\ddagger$ Co-senior author.

Abstract: Adult human subcutaneous adipose tissue (AT) harbors a rich population of mesenchymal stromal cells (MSCs) that are of interest for tissue repair. For this purpose, it is of utmost importance to determine the response of AT-MSCs to proliferative and inflammatory signals within the damaged tissue. We have characterized the transcriptional profile of cytokines, regulatory mediators and Toll-like receptors (TLR) relevant to the response of MSCs. AT-MSCs constitutively present a distinct profile for each gene and differentially responded to inflammation and cell-passaging. Inflammation leads to an upregulation of IL-6, IL-8, IL-1 $\beta$, TNF $\alpha$ and CCL 5 cytokine expression. Inflammation and cell-passaging increased the expression of HGF, IDO1, PTGS1, PTGS2 and TGF $\beta$. The expression of the TLR pattern was differentially modulated with TLR 1, 2, 3, 4, 9 and 10 being increased, whereas TLR 5 and 6 downregulated. Functional enrichment analysis demonstrated a complex interplay between cytokines, TLR and regulatory mediators central for tissue repair. This profiling highlights that following a combination of inflammatory and proliferative signals, the sensitivity and responsive capacity of AT-MSCs may be significantly modified. Understanding these transcriptional changes may help the development of novel therapeutic approaches.

Keywords: mesenchymal stromal cells; transcriptional profile; inflammation; cell-passage; TLR; cytokines; regulatory mediators

\section{Introduction}

Mesenchymal Stromal Cells (MSCs) have been shown to be a promising candidate for cell-based therapy [1]. They are relevant for tissue repair and wound healing because of their therapeutic properties. MSCs harbor specific functions such as immunomodulation, trophic support and in vitro differentiation ability into certain connective tissue 
cells upon specific inductive conditions [2]. Their therapeutic effects are mainly based on their secretome that include a variety of biologically active molecules such as chemokines, cytokines and other regulatory factors. These mediators may modulate diverse biological processes such tissue repair and regeneration, cell-progenitor differentiation and immune/inflammatory responses [3]. Studies have reported that MSCs can migrate and home to specific sites of injury and damage. Stromal cells, inflammation and immune cells are a critical component of the injured environment [4]. There are close interactions between MSCs and tissue local cells such as progenitors and immune cells. MSCs can interact with immune cells from both innate and adaptive immunity. MSCs may induce functional changes of monocytes/macrophages, dendritic cells, T cells, B cells and natural killer cells to finally regulate the immune response [5].

MSCs have been isolated from different tissues including bone marrow, skin, dental pulp and umbilical cord. Due to several concerns with the previous mentioned sources, adipose tissue has been proposed as a valuable alternative for MSCs [6]. Indeed, it is ubiquitously available, can be easily collected with minimal invasive procedure and most importantly harbor a high frequency of MSCs. Our laboratory has gained expertise in isolating MSCs from adipose tissue as well as in characterizing their features. According to the ISCT guidelines [7], MSCs are plastic-adherent in standard cell-culture conditions and display a special immunophenotype and differentiate to osteoblasts and adipocytes in vitro. Thus, MSCs have to present mesenchymal/stromal markers and lack expression of hematopoietic/immune markers. Despite sharing a same phenotype, the secretome of MSCs appears to vary depending on the source and cell-culture conditions of MSCs [8]. Functionally, MSCs are referred as sentinel and therapeutic responsive cells. Indeed, they are highly sensitive and can detect, through a large panel of receptors, stiffness of their environment. For instance, pathogens invading the injured tissue are recognized through pattern recognition receptors (PRRs) such as Toll-like receptors (TLRs). These receptors are expressed by various immune and non-immune cells and mediate signaling required to eliminate harmful stimuli and participate to tissue repair [9]. During the process of wound healing, MSCs may face inflammatory, proliferative and remodeling overlapping signals [10]. MSCs may also be potentially exposed to TLR ligands, which may result in the modulation of their activity and therapeutic efficiency [11,12]. In consequence, MSCs should respond adequately by expressing site-specific mediators that converge to establish a pro-regenerative environment [13].

Manufacturing of MSCs for therapeutic purposes often includes extended cell-expansion or inflammatory licensing. Although these cytokines, chemokines, regulatory mediators and TLR candidate genes are known [14], their profile and modulation under the pressures of cell-expansion and immune activation combination has not been formally investigated. Herein, we have investigated the impact of a combination of inflammation and cell-expansion signals on the transcript profile of genes linked to the immuno-reparative features of AT-MSCs. We have isolated MSCs from adipose tissue by means of the Ficoll gradient centrifugation method and performed several cell-passaging in the presence of inflammation. We found that the expression of cytokines/chemokines (IL-6, IL-8, IL-1 $\beta$, TNF $\alpha$ and CCL5), regulatory mediators (HGF, IDO1, PTGS1, PTGS2 and TGF $\beta$ ) and TLR was constitutively different. Of importance, inflammatory signaling and cell-passaging have significantly and differentially modulated these expression profile linked to tissue repair and regeneration. Upregulations of cytokines, regulatory mediator and TLR expression were highlighted demonstrating the great capacity of MSCs to sense and actively respond to tissue challenges. The complex interplay between MSCs, cytokines, TLR and regulatory mediators is central to the process of tissue repair. Moreover, functional enrichment analysis demonstrated that several biological process, molecular functions and cellular components linked to several TLR interaction networks are involved in inflammatory and immune response. Our findings will improve our knowledge regarding the influence of inflammation and cell-expansion on the immune-biology of AT-MSCs, as well as help to identify molecular targets that improve the therapeutic potential of MSCs. 


\section{Results}

\subsection{Source of MSCs}

Cells from adipose tissue were isolated by means of Ficoll gradient centrifugation and cultivated by the classical attachment culture method.

\subsection{The Culture Characteristics of MSCs}

In culture, we observed a heterogeneous population of fibroblastic-shaped cells highly adherent to plastic (Figure 1A).

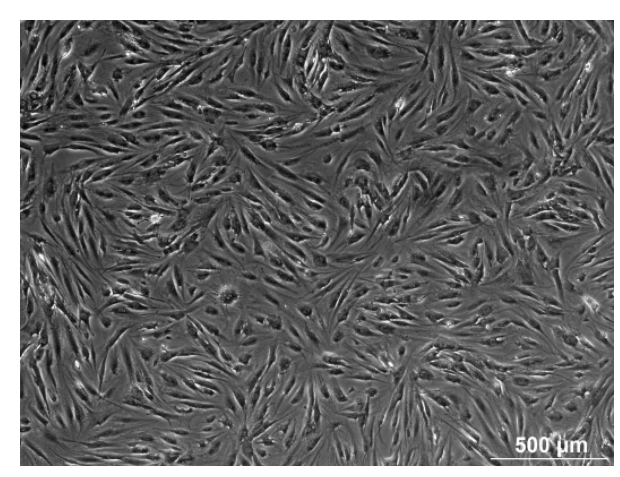

(A)

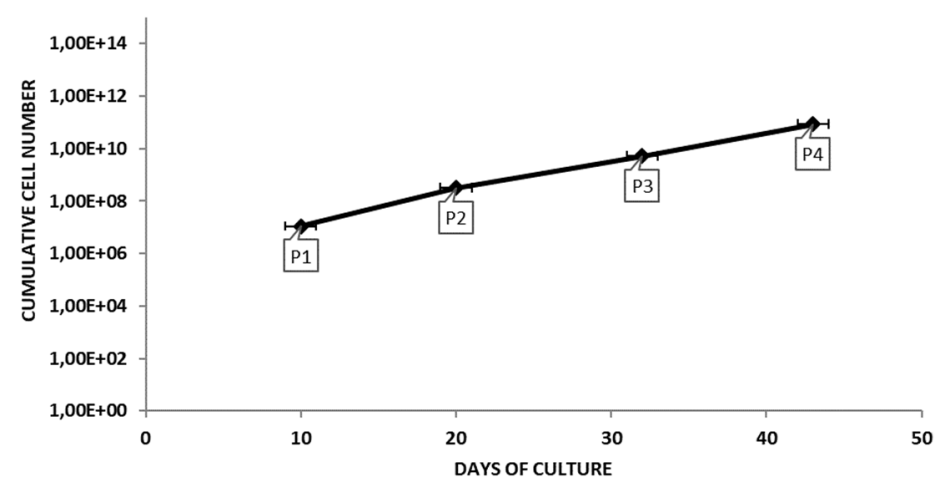

(B)

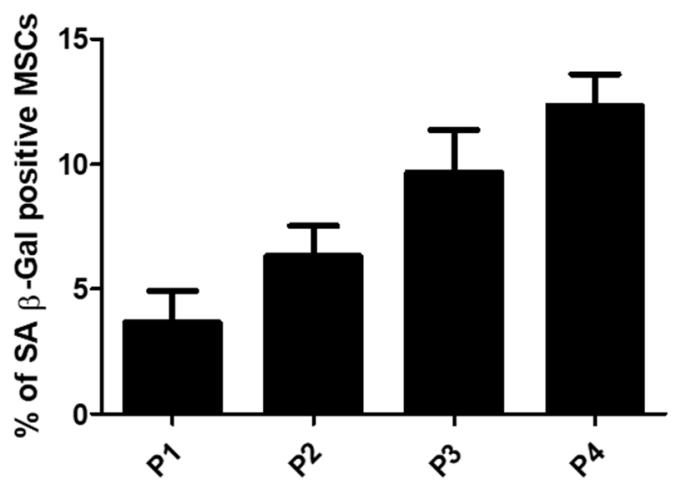

(C)

Figure 1. The culture characteristics of adipose MSCs. MSCs are derived from liposuction waste material. The cells are obtained by Gradient Ficoll Centrifugation and cultured by classical adherent method. (A) The image is representative for the morphology of MSCs. The cells are observed by light microscopy. Scale bar $=500 \mu \mathrm{m}$. (B) The cumulative cell number of MSCs at each passage as a function of culture time. (C) The percentage of SA $\beta$-Gal positive MSCs during passage expansion.

Cell expansion in culture by cell-passaging allowed to increase the number of MSCs as function of time. Passage 3 and 4 are reached after 32 (5.23E + 09 cells) and 43 (8.62E + 10 cells) days, respectively, with a constant and significant increase in the number of MSCs (Figure 1B). The transcriptional profile of AT-MSCs for cytokines, regulatory mediators and TLR was performed during early (P1-P2) and late (P3-P4) passage that are reached after 15 and 37.5 days, respectively.

In our culture, the level of senescence was very low during the expansion of MSCs and no significant changes was observed between the passages (Figure 1C). 


\subsection{Phenotype of MSCs}

MSCs from adipose tissue constitutively expressed the CD105, CD73 and CD90 markers whereas the expression of the CD34, CD45, CD14, CD19 and HLA-DR was negative.

Specifically, the \% of CD34 expression was in primo culture (PM) $19 \pm 1.06$ versus $17.83 \pm 1.08$, in early P $6.08 \pm 0.605$ versus $5.165 \pm 0.915$ and in late $P 1.42 \pm 0.33$ versus $1.415 \pm 0.2$ for basic and inflammation condition, respectively. The $\%$ of CD105 expression was in PM $85.33 \pm 4.39$ versus $66 \pm 13.89$, in early P $92.33 \pm 3.125$ versus $73.75 \pm 10.525$ and in late P $82.75 \pm 2.51$ versus $66.58 \pm 10.155$ for basic and inflammation condition, respectively. The \% of HLA-Dr expression was in PM $5.5 \pm 0.67$ versus $5.83 \pm 1.25$, in early P $2.915 \pm 0.32$ versus $2.085 \pm 0.38$ and in late P $1.165 \pm 0.105$ versus $1.165 \pm 0.105$ for basic and inflammation condition, respectively (Figure 2).

\subsection{Differentiation Potential of MSCs}

Osteogenesis: In contrast to cells cultivated under control conditions, osteoblasts could be detected after 3 weeks of osteogenic induction as shown by the mineral deposition supported by Alizarin Red S staining (Figure 3A). Adipogenesis: In contrast to cells cultivated under control conditions, adipocytes could be detected after 2 weeks of adipogenic induction, as shown by the accumulation of lipid droplets revealed by Oil Red O staining (Figure 3B).

PM

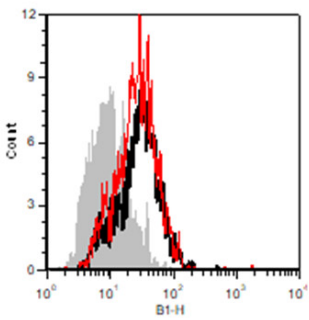

PM

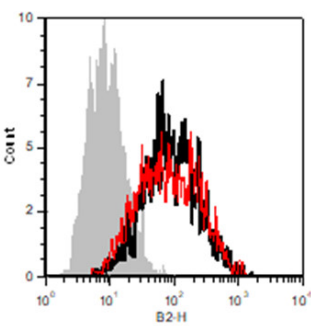

PM

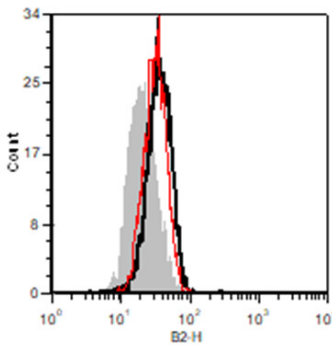

Early P

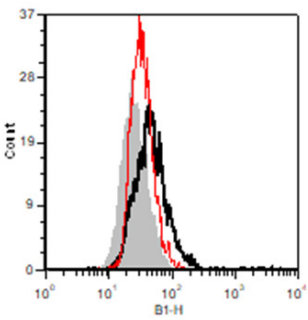

Early P

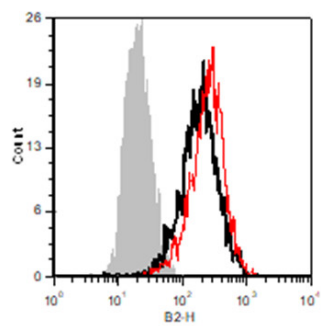

Early P

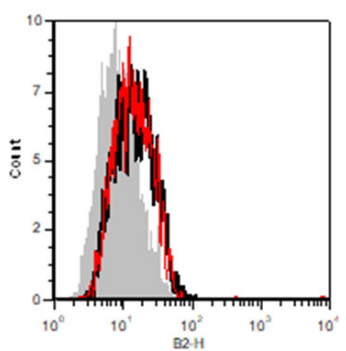

Late $\mathrm{P}$

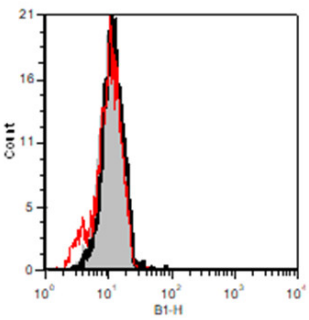

Late P

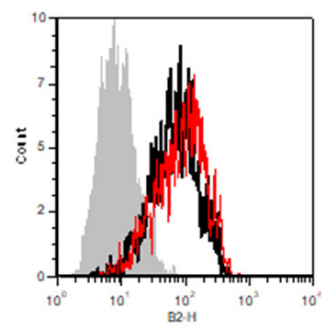

Late $\mathrm{P}$

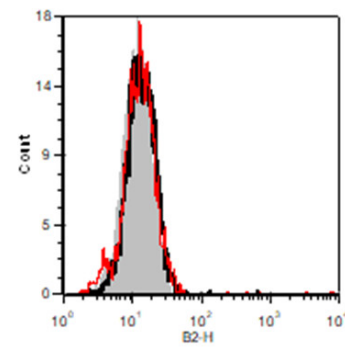

Figure 2. Cont. 

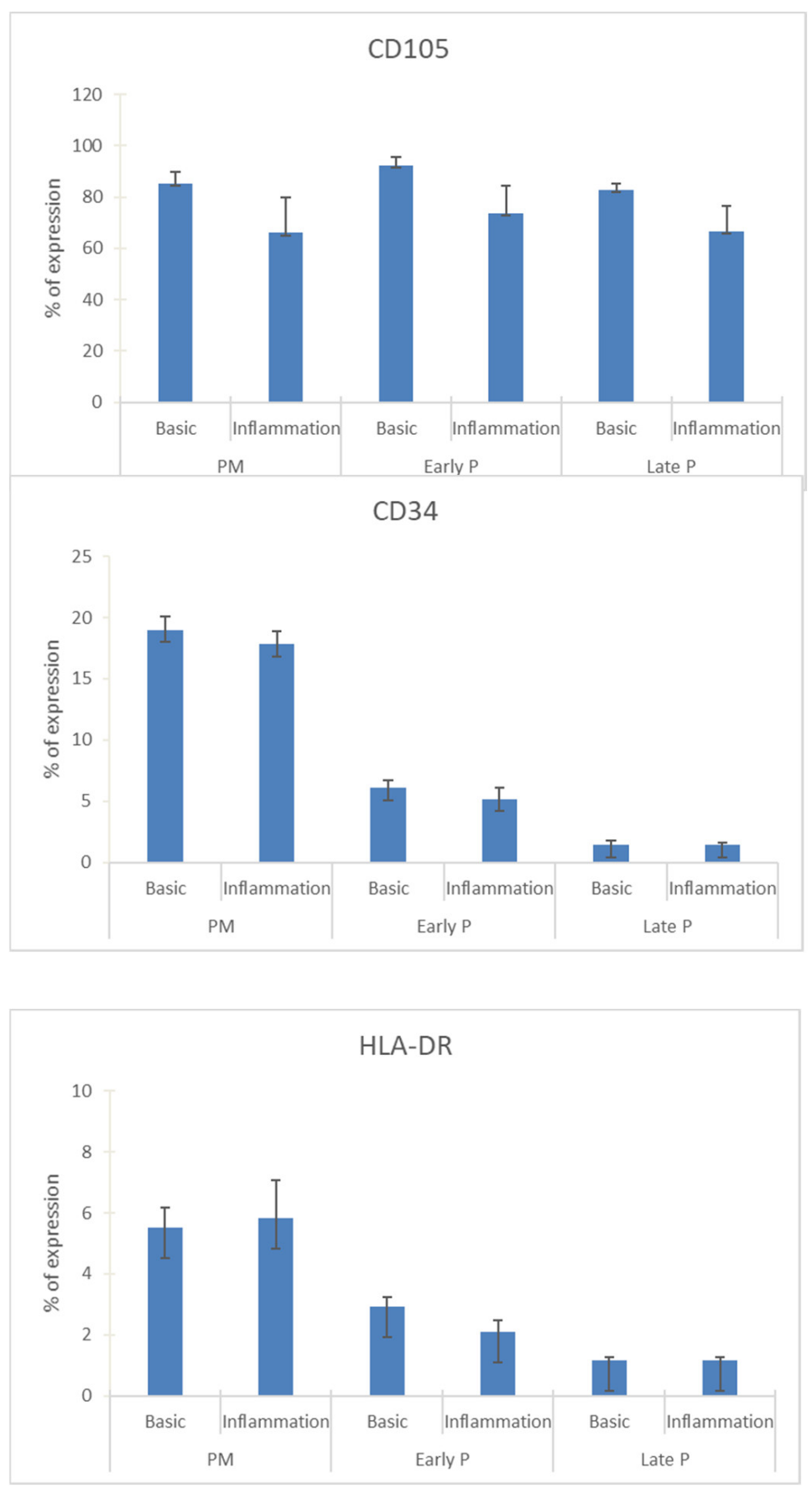

Figure 2. The expression profile of CD34, CD105 and HLA-Dr during cell expansion of MSCs. These markers were analyzed by flow cytometry. The results are presented in the graphic as the mean \pm SEM percentage of each marker expression. Representative FACS histograms are also shown for basic (black curve) and inflammation conditions (red curve) during PM, early and late passage cultures. The grey curve represents the antibody control.

\subsection{Upregulation of the Cytokine Expression Pattern of MSCs}

MSCs constitutively presented a panel of cytokines with different levels of expression (Figure 4). MSCs express interleukin (IL)-6 and IL-8 at high levels, while a lower expression is observed for the chemokine ligand CCL5, IL-1Ra and IL- $1 \beta$. In contrast, almost no expression of tumor necrosis factor (TNF $\alpha)$ was detected in MSCs. The presence of inflammatory stimulation leads to an upregulation of all cytokine expression regardless of their culture expansion condition. After inflammatory stimulation, IL-6, IL-8, IL-1 
IL-1Ra, TNF $\alpha$ and CCL5 are expressed at higher levels compared to control condition. More specifically, IL-6, IL- 8 and IL-1 $\beta$ are significantly upregulated in the primo culture (99.8-fold; 159.2-fold; 130.9-fold, respectively) and late passage (P3-P4) (23.0-fold; 9.8-fold; 41.0-fold, respectively) condition. The same is observed for TNF $\alpha$ (18.0-fold for PM and 5.1-fold for late P) and CCL5 (377.9-fold for PM and 50.6-fold for late P) and on top these cytokines show also a significantly higher expression in the early passage (P1-P2) (7.2fold and 151.8-fold, respectively) condition. For IL-1Ra, a significantly higher expression (5.8-fold) is observed for the PM condition after pro-inflammatory stimulation compared to the non-inflammatory situation. Further, the cell-passaging is likely to not influence the expression of all these cytokines. More specifically, no significant differences were observed between the primo culture condition, the early (P1-P2) passage condition and the late (P3-P4) passage condition.

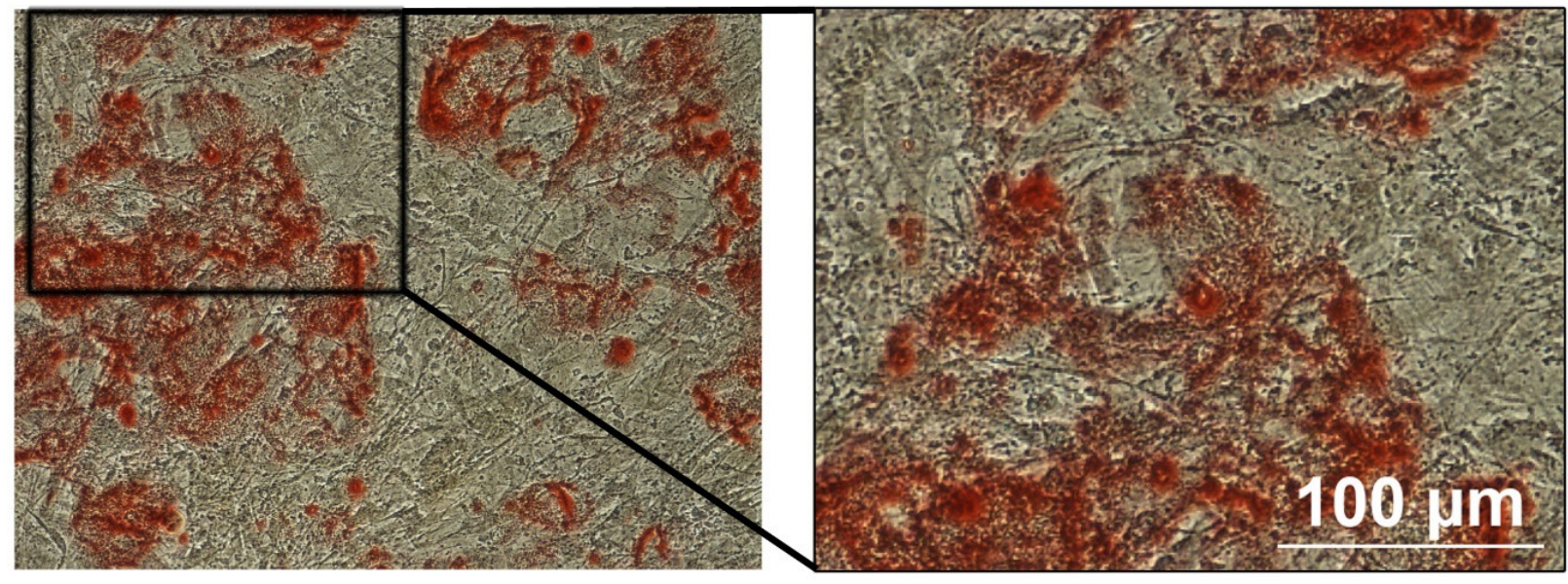

(A)

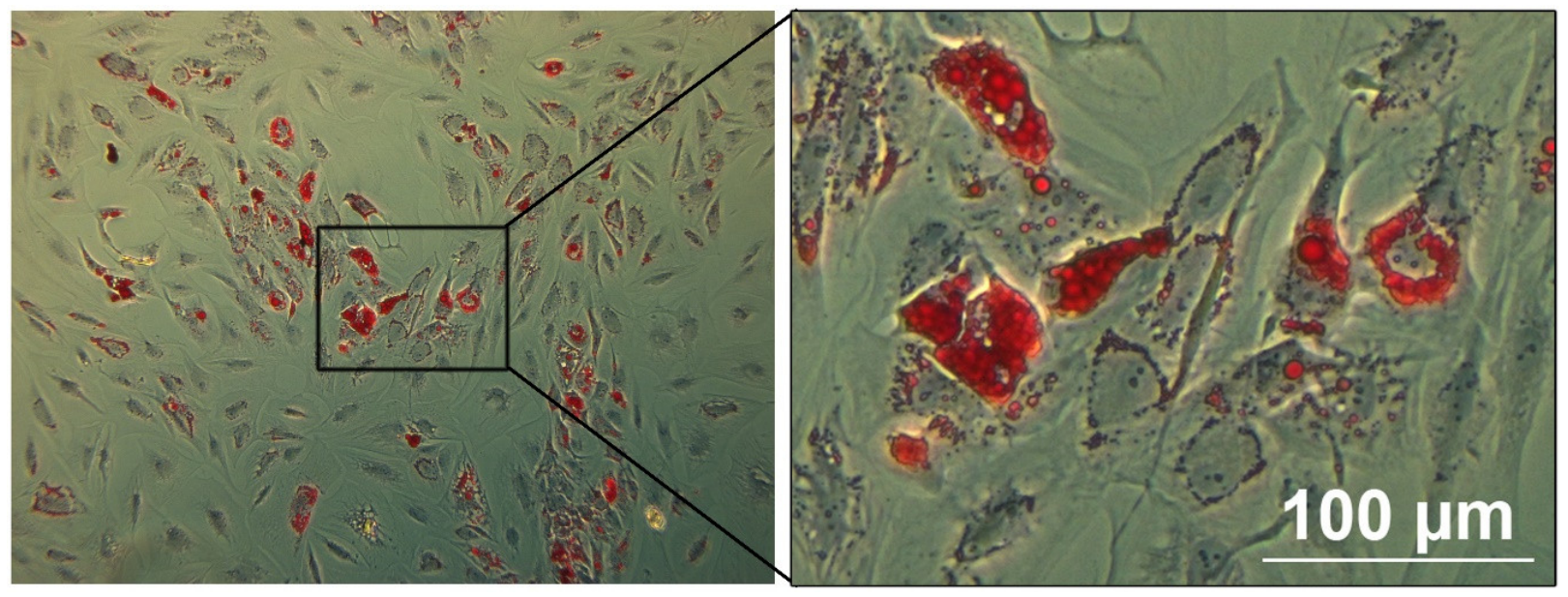

(B)

Figure 3. The differentiation potential of adipose MSCs is confirmed by light microscopy. The osteogenic and adipogenic differentiation of MSCs are carried out in specific induction media and confirmed by using lineage-staining techniques. The images are representative for MSCs differentiated into osteoblast (A) and adipocytes (B), being confirmed by using Alizarin Red (calcium deposits) and Oil red O (Lipid vacuoles) staining, respectively. Scale bar $=100 \mu \mathrm{m}$. 
IL-6

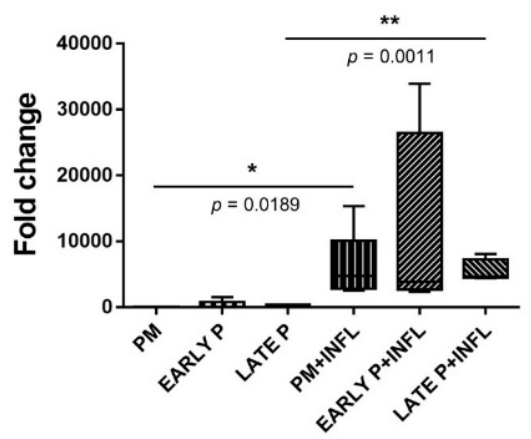

IL-1 $\beta$

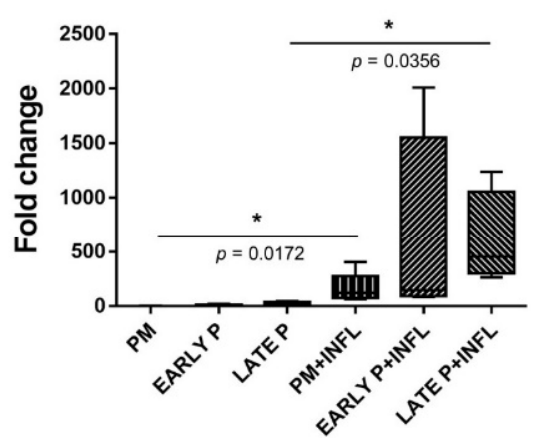

CCL5

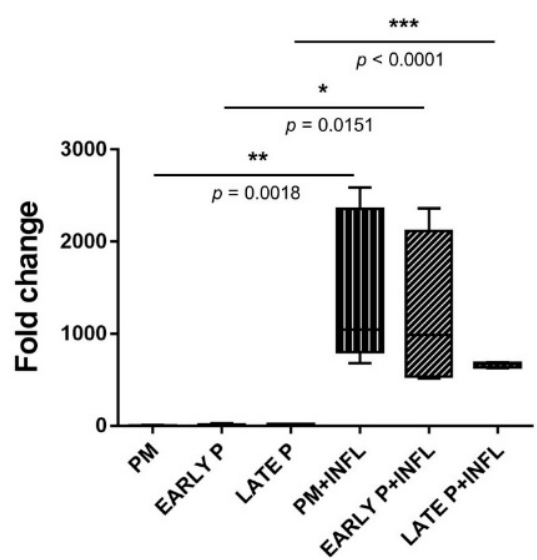

IL-8

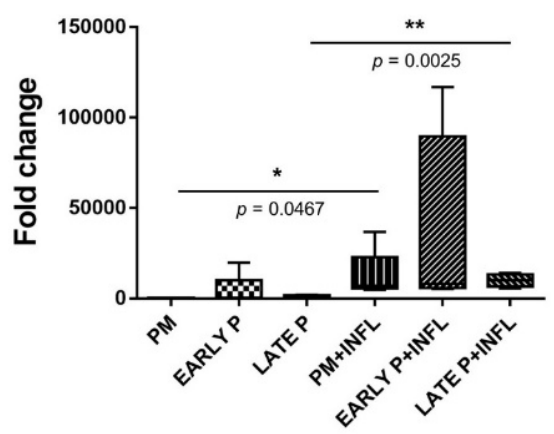

IL-1Ra

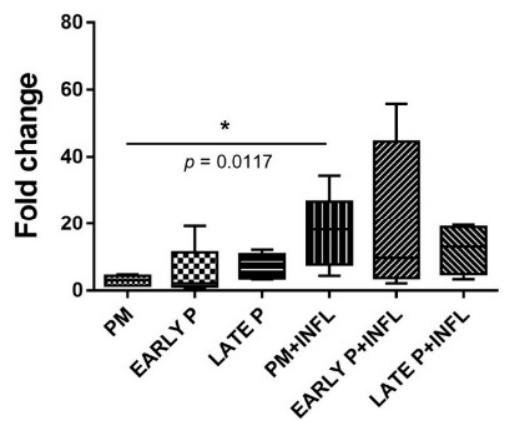

TNFa

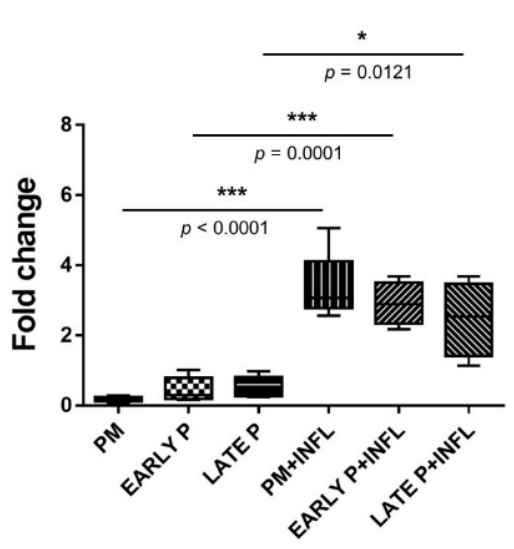

Figure 4. The expression of cytokines is upregulated in MSCs. The gene expression level of each cytokine is determined by qPCR analysis from basic MSCs and inflamed MSCs (INFL) during the primo culture (PM), early (EARLY) and late (LATE) passage (P). The values are expressed as mean \pm SEM compared to the expression of the housekeeping gene (ACTB and GAPDH). * ${ }^{* *}, * * *$ Significant increase of expression of inflamed MSCs (INFL) versus basic MSCs ( $p$-value: $p \leq 0.05, p \leq 0.01, p \leq$ 0.001 , respectively). 


\subsection{Upregulation of the Regulatory Mediator Expression Pattern of MSCS}

MSCs constitutively presented a panel of regulatory mediators with different levels of expression (Figure 5). MSCs express moderate level of heme oxygenase (HMOX)-1, insulin-like growth factor binding-protein (IGFBP) 3 and transforming growth factor (TGF)$\beta 1$. Leukemia inhibitory factor (LIF), prostaglandin endoperoxide synthase (PTGS)1 and PTGS2 are expressed at low levels, whilst the expression of hepatocyte growth factor (HGF), indoleamine 2,3-dioxygenase (IDO)1, IDO2, IGFBP2 and HLA-G is insignificant. Both inflammatory signaling and cell-passaging differentially modulated these expression profiles. No significant differences are detected for the expression of HLA-G, IGFBP2, IGFBP3 and LIF despite the cell-passaging or inflammatory setting. Of note, the level of IGFBP3 expression was substantially more elevated than that of IGFBP2. Although, no significant differences are observed for the expression of HGF, IDO1, IDO2 and PTGS2 during the cell-passaging, a significant effect of inflammation is noted. On the other hand, a significant lower expression is perceived for HMOX1 $(33.16 \% \pm 8.92 \%$ to $62.41 \% \pm 4.49 \%)$, PTGS1 $(8.45 \% \pm 1.10 \%$ to $14.59 \% \pm 1.70 \%)$ and TGF $31(54.94 \% \pm 3.93 \%$ to $92.84 \% \pm 8.99 \%)$ in the PM compared to the early passage condition. When comparing the inflammatory and non-inflammatory groups, a significant higher expression is observed for IDO1 and IDO2 in the PM $(913.10 \% \pm 154.30 \%$ to $0.03 \% \pm 0.01 \%$ and $0.05 \% \pm 0.01 \%$ to $0.00 \% \pm$ $0.00 \%$, respectively) and early passage $(890.30 \% \pm 275.30 \%$ to $0.14 \% \pm 0.12 \%$ and $0.08 \% \pm$ $0.02 \%$ to $0.00 \% \pm 0.00 \%$, respectively) condition. In contrast, PTGS1 displayed a significant lower expression for PM $(4.03 \% \pm 0.51 \%$ to $8.50 \% \pm 1.10 \%)$ and early passage $(7.38 \% \pm$ $0.89 \%$ to $14.59 \% \pm 1.70 \%$ ) and on top a significant difference is detected for the late passage $(8.48 \% \pm 1.36 \%$ to $18.04 \% \pm 2.78 \%)$ condition after inflammatory stimulation. The same is true for TGF $\beta 1$ : a significant lower expression is detected for the PM $(37.27 \% \pm 1.82 \%$ to $54.94 \% \pm 3.93 \%)$, early $\mathrm{P}(43.05 \% \pm 1.31 \%$ to $92.84 \% \pm 8.99 \%)$ and late $\mathrm{P}(41.68 \% \pm 6.59 \%$ to $79.14 \% \pm 9.27 \%$ ) condition after inflammatory stimulation. For HGF and PTGS2, only a significant upregulation is observed for the PM $(4.13 \% \pm 0.73 \%$ to $1.50 \% \pm 0.35 \%$ and $44.05 \% \pm 13.00$ to $1.79 \% \pm 0.44 \%$, respectively) condition upon inflammatory stimulation.

\subsection{Differential Expression and Regulation of TLR in MSCs}

The expression of TLR in AT-MSCs is constitutively different and differentially regulated by both inflammation and cell-expansion (Figure 6). MSCs constitutively express 4 at low levels, whilst the expression of TLR1-3 and TLR5-10 was barely detected. After inflammatory stimulation, the expression of TLR1-10 is overall significantly higher, with exception of TLR5 and TLR6. The expression of TLR 1, 2,3, 4, 9 and 10 is increased, whereas TLR 5 and 6 are downregulated. More specifically, for TLR2, TLR3, TLR9 and TLR10, a significantly higher expression is observed in the PM (28,3-fold; 56.1-fold; 2.8-fold and 3.6-fold, respectively), the early (686.4-fold; 151.8 -fold; 5.6 -fold and 8.5-fold, respectively) and the late passage (224.7-fold; 79.2-fold; 3.0-fold and 3.7-fold, respectively) condition after inflammatory stimulation compared to the non-inflammatory group. The expression of TLR1 and TLR4 in MSCs is significantly upregulated in the PM (3.0-fold and 2.6-fold, respectively) and the late passage (6.1-fold and 2.5-fold, respectively) condition after inflammatory stimulation. For TLR6 on the other hand, a significantly lower expression is observed for the PM (0.5-fold) and the late passage (0.3-fold) condition upon inflammatory stimulation. On the other hand, both conditions induced a mixed gene expression profile for TLR 7 and 8. MSCs show a significantly higher expression of TLR7 after exposure to inflammatory stimulation for the PM (2.9-fold) and early passage (66.9-fold) condition, whilst the expression of TLR8 is a little, but still significantly upregulated in the PM (2.5fold) condition. Although the expression of TLR7-TLR10 is significantly upregulated upon inflammatory stimulation, it should be noted that their expression is almost not detected. No difference in expression is observed for TLR5 in the non-inflammatory and inflammatory group. Further, the cell-passaging is likely to not influence the expression of all these TLRs, with exception of TLR1 and TLR2. More specifically, no significant differences are observed between the PM condition, the early (P1-P2) passage condition and the late 
(P3-P4) passage condition. TLR1 and TLR2 are significantly higher expressed in the PM condition compared to the early passage condition (6.4-fold and 21.9-fold, respectively). Protein-protein interaction (PPI) network analysis was constructed and dissected for the identified TLRs. This part of the results was inserted within the discussion.
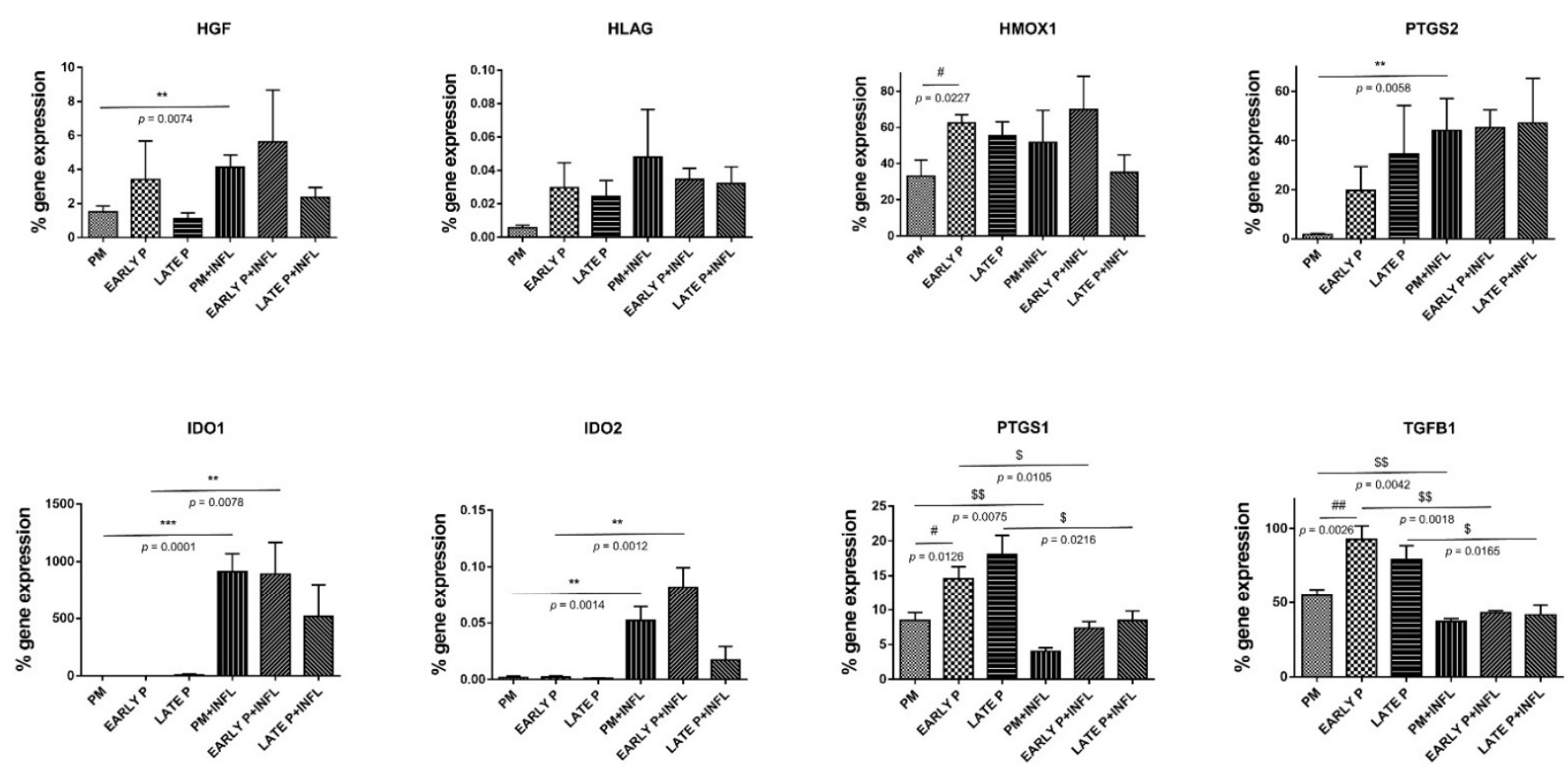

IGFBP2

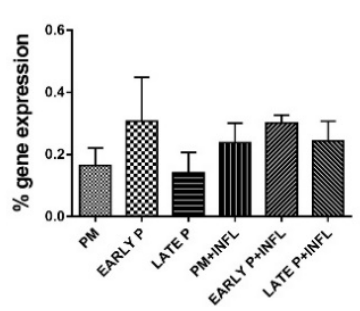

IGFBP3

LIF
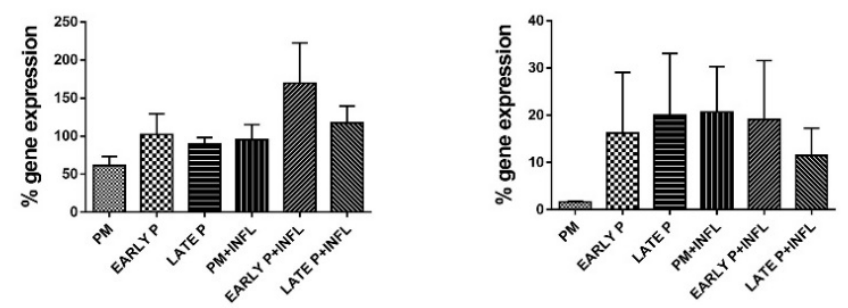

Figure 5. The expression of regulatory mediators is upregulated in MSCs. The gene expression level of each cytokine is determined by qPCR analysis from basic MSCs and inflamed MSCs (INFL) during the primo culture (PM), early (EARLY) and late (LATE) passage (P). The values are expressed as mean \pm SEM compared to the expression of the housekeeping gene (ACTB and GAPDH). ${ }^{* *},{ }^{* * *}$ Significant increase of expression of inflamed MSCs (INFL) versus basic MSCs ( $p$-value: $p \leq$ $0.01, p \leq 0.001$, respectively). $\$$, \$, Significant decrease of expression of inflamed MSCs (INFL) versus basic MSCs ( $p$-value: $p \leq 0.05, p \leq 0.01$, respectively). \#, \#\# Significantly lower expression compared to the consecutive passage ( $p$-value: $p \leq 0.05$, $p \leq 0.01$, respectively). 

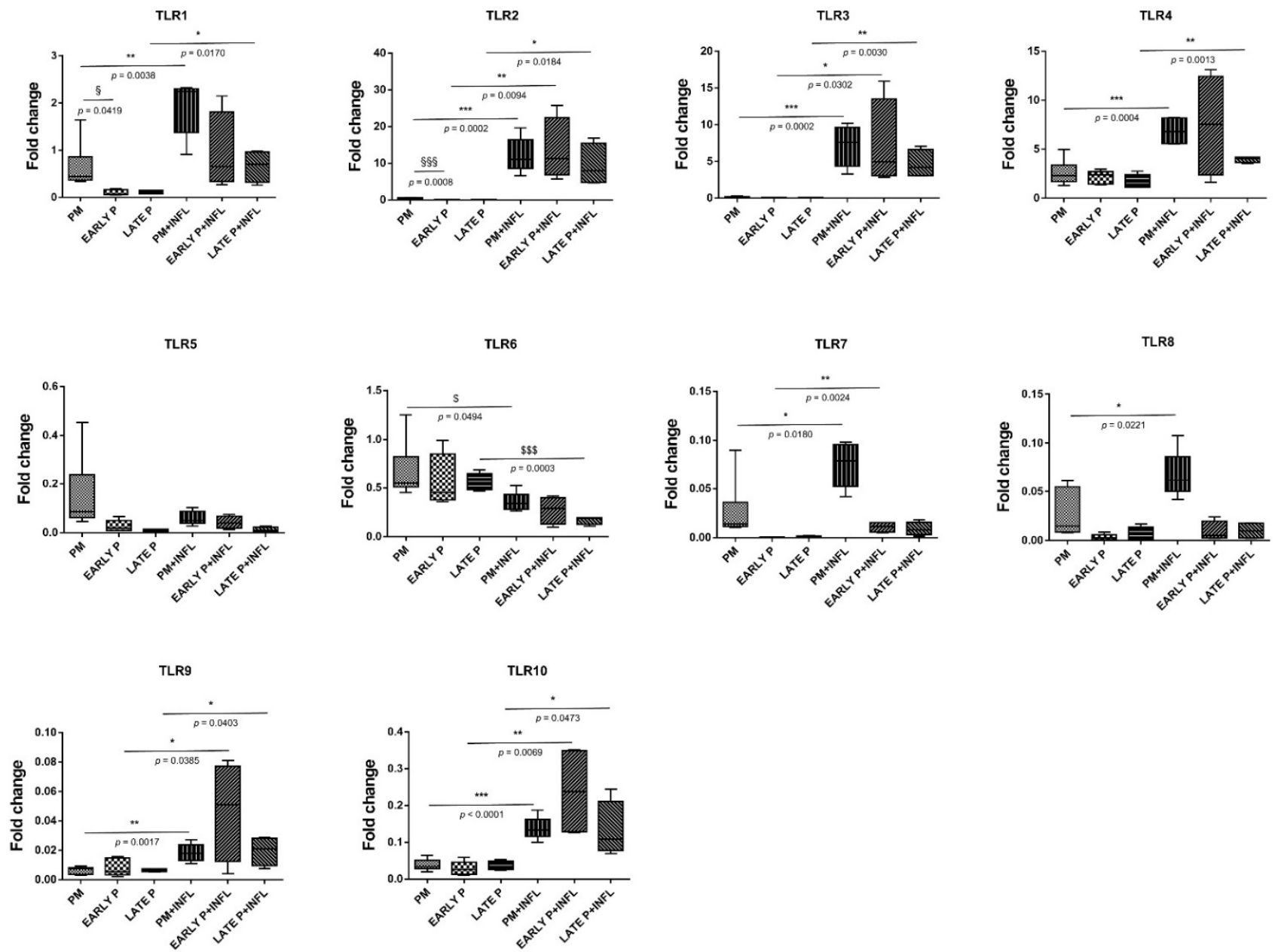

Figure 6. Distinct expression of Toll-like receptor (TLRs) and differential regulation in MSCs. The gene expression level of each cytokine is determined by qPCR analysis from basic MSCs and inflamed MSCs (INFL) during the primo culture (PM), early (EARLY) and late (LATE) passage (P). The values are expressed as mean \pm SEM compared to the expression of the housekeeping gene (ACTB and GAPDH). ${ }^{*} * * * * *$ Significant increase of expression of inflamed MSCs (INFL) versus basic MSCs ( $p$-value: $p \leq 0.05, p \leq 0.01, p \leq 0.001$, respectively). $\$$, $\$ \$$ Significant decrease of expression of inflamed MSCs (INFL) versus basic MSCs ( $p$-value: $p \leq 0.05, p \leq 0.001$, respectively). $\S$, \&§§ Significantly higher expression compared to the consecutive passage ( $p$-value: $p \leq 0.05, p \leq 0.001$, respectively).

\section{Discussion}

Adipose tissue is considered an interesting alternative source of therapeutic MSCs for immunomodulation and regenerative medicine $[15,16]$. Increasing our knowledge regarding the influence of the tissue environment on the immuno-biology of AT-MSCs will contribute to the development of novel therapeutic approaches [17,18]. AT-MSCs in culture demonstrated a fibroblastic-like shape with a high capacity to adhere to plastic. The expansion of MSCs by cell-passaging allowed to increase their number without any significant sign of senescence. In general, AT-MSCs are relatively stable over long-term culture, maintaining a consistent expansion rate and exhibiting low levels of senescence [19]. Senescence may alter some features of MSCs, in particular at high passage level or in presence of cellular stress and damage [20]. Despite AT-MSCs differentiated in vitro into in osteoblasts and adipocytes, their beneficial effect seems to come from their immunomodulation and trophic ability rather than their multilineage potential [21]. The phenotype of AT-MSCs (Figure 2) presented the stromal surface markers CD105, CD90 and CD73 [22]. They lack expression of hematopoietic cell lineage markers CD45, CD14 and CD19. HLA-Dr considered as marker for antigen presenting cells (APCs) was not expressed. According to the 
ISCT, this phenotype is essential to define MSCs [7]. The absence of CD45, HLA-Dr, CD14 and CD19 expression is used to exclude contamination of cell-cultures by pan-leukocytes, APCs, monocytes/macrophages and B cells, respectively. Thus, AT-MSCs are not immunogenic and could not induce T-lymphocyte activation which is essential for preventing immune complication and graft rejection [23,24]. The expression of CD105 is reported to vary according to culture conditions and some findings indicate that distinct expression of CD105 might be related to specific multilineage and immunomodulatory potentials [25,26]. Considered as an endothelial marker, the expression of CD34 rapidly decreases during the cell-expansion. The variation some surface markers between freshly isolated cells and cells in culture is reported to be dependent on the tissue source of MSCs [27,28]. MSCs from adipose tissue are being considered CD34+ in situ and may represent a small proportion of the total cell population indicating a distinct subset of cells with enhanced progenitor activity [29-32]. The success of the reparative strategy based on the use of MSCs might be hampered by the harsh environment of injured tissue that is generally associated with inflammation/immunology reactions $[33,34]$. Wound healing is a complex process involving inflammatory, proliferative and reparative events $[1,35,36]$. Such process is mediated in large part by interacting molecular signals, primarily cytokines, chemokines, TLR and regulatory mediators that may greatly influence the recruitment, proliferation and engraftment of progenitor cells to expand the pool of therapeutic cells [37,38]. Consequently, it is essential to determine the transcriptional profile of these immunomodulatory and trophic mediators under challenging conditions [10].

We found that MSCs constitutively presented a distinct profile for each pattern of cytokine and chemokine. In addition to displaying different levels of expression, MSCs differentially and to some extent specifically modulated them in response to inflammation and cell-passaging. The cytokines IL-6, IL-1 Ra, IL-1 $\beta$ and TNF $\alpha$ as well as the chemokine IL-8 and CCL5 were constitutively presented by MSCs with different levels of expression. Moreover, we found that the expression of IL-6, IL-8, TNF $\alpha$ and CCL5 is downregulated upon cell passaging. This change in the cytokine profile suggests that MSCs are less interacting and soliciting the immune system during the proliferative phase of regeneration. On the other hand, the inflammatory setting differentially altered the cytokine profile of MSCs. A significant increase of IL-6, IL-8, IL-1 $\beta$, IL-1Ra, TNF $\alpha$ and CCL5 expression is reached. It is likely that MSCs respond by promoting a pro-inflammatory environment suitable for tissue repair. Both IL- 1 and TNF- $\alpha$ are always present during wound repair, but their pleiotropic and synergistic effects are not well understood. Moreover, it is suggested that TNF- $\alpha$ plays a role in wound healing process by promoting the recruitment and differentiation of tissue stromal cells [39]. In line with our observations, altered levels of TNF- $\alpha$, IL-1 and IL- 6 appear to be regulated differently in the early versus later chronic phases of wound healing, with overexpression dominating the later phases [40]. In parallel, recent results showed that, early in obesity and before inflammation was detected, high-fat (HF) diet durably and differently activated adipose stem cells (ASC) from the subcutaneous (SAT) and the visceral adipose tissue (VAT). Subcutaneous ASC from HF-fed mice strongly inhibited the proliferation of activated $\mathrm{T}$ lymphocytes, whereas visceral ASC selectively inhibited TNF $\alpha$ expression by macrophages and simultaneously released higher concentrations of IL6 [34]. These depot specific differences may contribute to the low-grade inflammation that develops with obesity in VAT while inflammation in SAT is delayed. It was reported that IL-6 is involved in the suppression of T-cell proliferation and local inflammation. This is an important finding, since we showed that MSCs significantly higher express IL-6 upon inflammation, which can reduce the rejection of transplanted allogeneic MSCs and enhance their capacity for tissue repair and regeneration [41]. A high level of chemokines and inflammatory cytokines, including CCL2, IL-1 $\beta$ and TNF $\alpha$, allow an accumulation of M1 macrophages that further increased TNF $\alpha$ production to activate stem cells. Moreover, IL- $1 \alpha$, IL-13, IFN $\gamma$ and TNF $\alpha$ cytokines may promote stem cell expansion and thus replenish their endogenous pool. These findings illustrate a cross-talk between stem cells and immune responses that determines the function and fate of stem 
cells in the process of tissue regeneration [42]. In agreement, we have shown that MSCs within an inflammatory environment increase the recruitment of T-cells by increasing IL-8 and CCL 5 secretion. Following their migration, MSCs can impair lymphocyte proliferation and activation depending on their origin [43]. Reduced activation of inflammasome and suppressed production of IL- $1 \beta$ in macrophages were mainly responsible for beneficial effects of MSCs in many injured tissue model [44]. Upregulation of IL-1Ra will also favor allograft integration by blocking IL- $1 \beta$-mediated cellular changes by competitive binding on their receptor [45]. Enhanced release of chemokines (CCL5, IL-8) and cytokines (TNFa, IL-1 and IL-6) may modulate the features of neutrophil and macrophage known to cooperate during tissue repair [46]. The modulation of these cytokines and chemokines may be considered as a novel therapeutic approach in regenerative medicine [47].

We also evaluated the expression of regulatory mediators that are important for the control of wound healing process. MSCs constitutively presented different levels of expression HGF, HMOX1, IGFBP3, LIF, PTGS, PTGS2 and TGF $\beta 1$. We noted that neither the cell-passaging nor the inflammatory setting have modulated the expression profile of HLA-G, IGFBPs and LIF. We can speculate that these mediators, in a tissue-context dependent manner, are expressed and my participate to the tissue repair process driven by MSCs. Interestingly, TGF- $\beta 1$ demonstrated a significant decrease upon inflammation despite an initial at high level. It seems that TGF- $\beta 1$ is necessary for tissue repair at the earliest stages, although the molecule has inflammatory or anti-inflammatory effects depending on the cell type involved as well as the tissue context [38]. In contrast, AT-MSCs constitutively expressed low levels of HGF that was significantly increased under inflammatory setting regardless of the cell-passaging. HGF is an important factor for tissue repair by stimulating the proliferation and migration of respective progenitor cells $[48,49]$. The increase of HGF can also promote a M2 macrophage shift and regulatory T-cell generation that facilitates tissue regeneration [50]. Regardless of inflammatory setting, AT-MSCs constitutively maintained high levels of HO-1 with significant expression starting in PM condition. HO-1 is a highly inducible enzyme with cytoprotective, antioxidant and immunoregulatory properties that participate to tissue protective and adaptive responses [51]. In contrast to Mougiakakos D et al., we have not observed that inflammatory licensing of MSCs substantially altered HO-1 expression that compromise their immunomodulatory functions [52]. Of note, $\mathrm{HO}-1$ was upregulated in BM-MSCs with a concomitant increase in the secretion of IL-1RA confirming that HO-1 couples activation of mitochondrial biogenesis to anti-inflammatory cytokine expression [53]. As previously documented, the expression and modulation of HO-1 by MSCs is dependent on cell-conditions and HO- 1 is not mandatory for inducing a tolerogenic response [54]. In parallel, the expression of IDO1 and IDO2, two important immunoregulatory enzymes, was significantly upregulated by inflammation during PM and early culture condition. Such increase should be correlated with the fact that under inflammatory setting IDO are stimulated by MSCs [55]. A sustained IDO expression may thus create a local immune privilege that protects tissues from damage and allows tissues to heal [56]. The opposite effect was reported for the enzymes involved in the production of prostaglandin (PG) E2. PTGS1 (cyclo-oxygenase 1, COX1) and PTGS2 (COX2) were differentially modulated by inflammation with PTGS1 being significantly decreased, whereas PTGS2 was upregulated. To avoid exacerbation of tissue injury, regulatory pathways (IDO, HO-1, PGE2) are activated and allows to dampen the inflammatory response. At sites of injury, PGE2 production may promote the polarization of neutrophil and macrophage towards a tolerogenic phenotype appropriate for tissue repair and regeneration $[57,58]$.

We then observed that several TLRs were differentially expressed by AT-MSCs and significantly modulated by both cell-passaging and inflammation. The significant modifications documented for TLR expression will be discussed according to the importance and degree of the changes. Transplanted cells such as MSCs are often exposed, within injured tissues, to unfavorable conditions. TLRs acting as sentinels sense "danger signals" which, in turn, may affect the tissue repair process $[59,60]$. TLR are thus, instrumental in coordi- 
nating tissue repair and regeneration in a time and expression dependent manner [61]. The literature indicates that the source of MSCs as well as culture conditions may influence the expression profile of TLR [60]. As a comparison, dental pulp stem/progenitor cells (DPSCs) basically expressed high levels of TLR. In an inflamed environment, it upregulated TLR2, TLR3, TLR4, TLR5 and TLR8; downregulated TLR1, TLR7, TLR9 and TLR10; and abolished TLR6 expression [62]. TLRs triggers expression of genes mainly linked to innate immune responses through the utilization of specific or common signaling pathways. They are finely regulated by TIR (toll/IL-1 receptor) domain-containing adaptors, such as MyD88, TIRAP/Mal, TRIF and TRAM [63]. It has been reported that under in vitro hypoxic conditions, the expression of specific TLR is affected [64]. As TLR2 was significantly upregulated during cell-expansion in the presence of inflammation, it may promote the proliferation of MSCs and the production of vascular endothelial growth factor (VEGF) IL-6, IL-8 and $\mathrm{TNF} \alpha$ during which are required in the early phases of tissue regeneration injury [65-67]. On the other hand, TLR3 and TLR 4 have been described to be involved in tissue repair according to several experimental settings [68]. A substantial augmentation of both TLR expression is reached under inflammation setting and may result in the increase of IL-6 and IL-8 expression, which allows MSCs to induce M2 type monocytes polarization that play important roles during tissue injury repair [69,70] [71]. Moreover, MyD88 was shown to regulate the proliferation and differentiation of AT-MSCs [72,73]. In turn, the expression of TLR5, TLR6, TLR7, TLR8, TLR9 and TLR10 was low and not altered by cell-expansion and inflammation except for TLR5 (increase) and TLR6 (decrease). MSCs from umbilical cord blood [74] and amnion [75], showed increase of cytokines and chemokines associated with their TLR5 and TLR6 expression. This increase may promote the migration of MSCs from adipose tissue to target tissues [76] as well as favor a tolerogenic environment suitable for tissue regeneration [77]. Finally, as differential utilization of TIR domain-containing adaptors may provide specificity of individual TLR-mediated signaling pathways, we aimed to have a view on the proteins and functional interactions that may occur. Using STRING v11 [78], we visualized TLR interaction networks (Figure 7) and performed gene-set enrichment analysis (Figure 8). TLR may establish several networks, interactions and associations with different proteins. Functional enrichment analysis showed that several biological process, molecular functions and cellular components linked to TLRs are involved in inflammatory and immune response. Decrypting how all of these pathways act in concert with one another will help to better define the regulatory network by which AT-MSCs induce the repair of the tissue environment. 

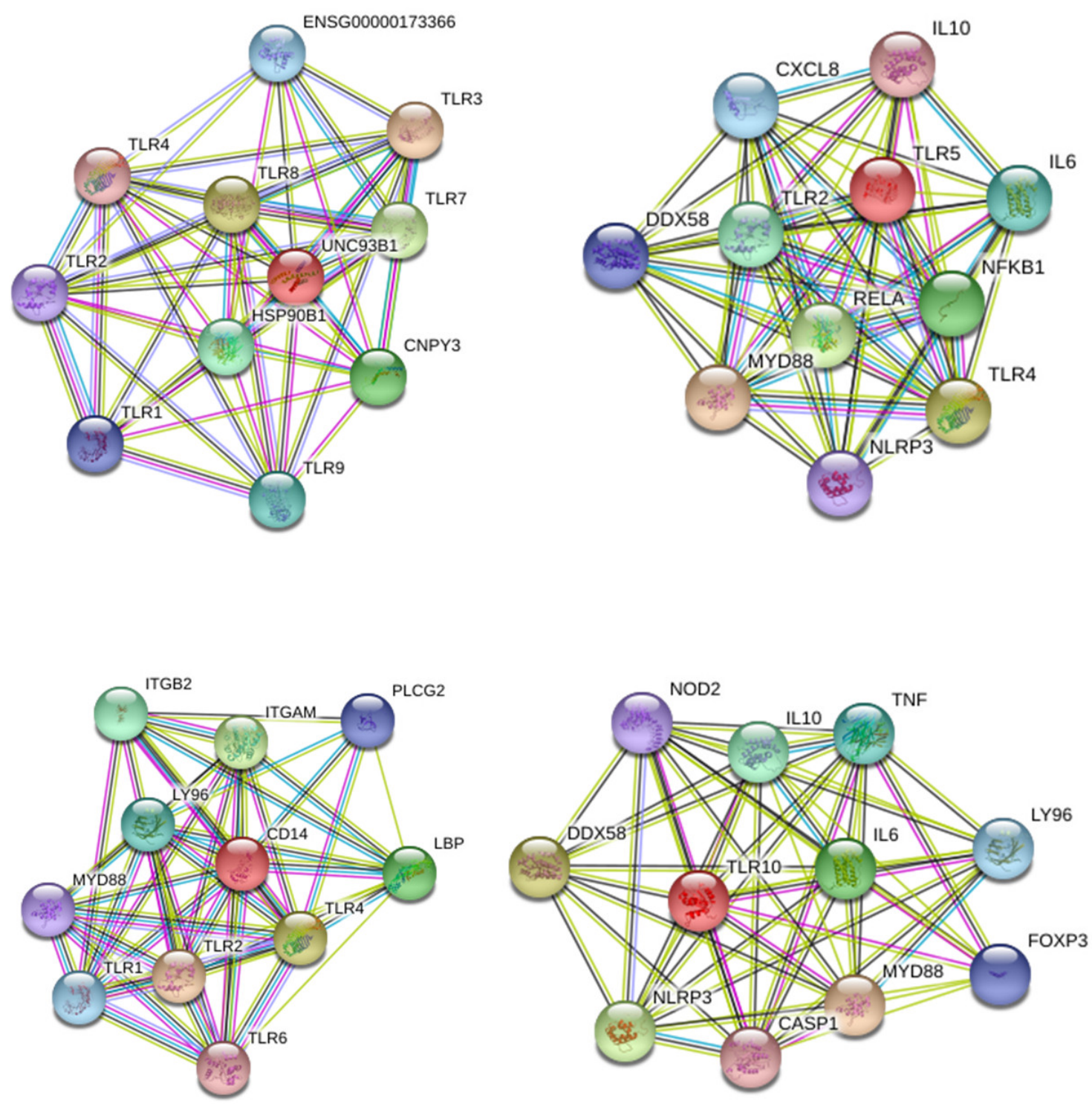

Figure 7. STRING 11.0 analysis of known and predicted TLR-protein interactions. The interactions include direct (physical) and indirect (functional) associations. Network nodes represent proteins and edges represent protein-protein associations (specific and meaningful). The lines represent the existence of the several types of evidence used in predicting the associations (high confidence score 0.9). The interactions are shown in different colors: black is co-expression; dark blue is co-occurrence; purple is experimental evidence; light green is text mining. 


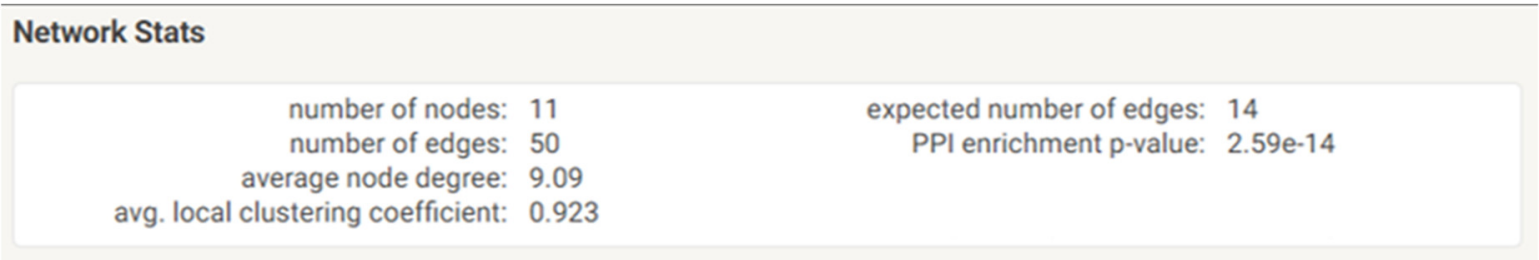

Functional enrichments in your network

\begin{tabular}{|c|c|c|c|}
\hline \multicolumn{4}{|c|}{ Biological Process (G0) } \\
\hline GO-term & description & count in gene set & false discovery rate \\
\hline G0:0002224 & toll-like receptor signaling pathway & 11 of 87 & $2.26 \mathrm{e}-23$ \\
\hline G0:0032757 & positive regulation of interleukin-8 production & 8 of 48 & $3.23 e-17$ \\
\hline G0:0032755 & positive regulation of interleukin-6 production & 8 of 74 & $6.84 \mathrm{e}-16$ \\
\hline G0:0032728 & positive regulation of interferon-beta production & 7 of 32 & $1.26 \mathrm{e}-15$ \\
\hline G0:0002755 & MyD88-dependent toll-like receptor signaling pathway & 7 of 33 & $1.43 e-15$ \\
\hline & & & (more ...) \\
\hline \multicolumn{4}{|c|}{ Molecular Function (GO) } \\
\hline GO-term & description & count in gene set & false discovery rate \\
\hline G0:0038023 & signaling receptor activity & 8 of 1429 & $2.60 \mathrm{e}-06$ \\
\hline GO:0035325 & Toll-like receptor binding & 3 of 10 & $2.60 \mathrm{e}-06$ \\
\hline GO:0035197 & siRNA binding & 3 of 10 & $2.60 \mathrm{e}-06$ \\
\hline G0:0005102 & signaling receptor binding & 8 of 1513 & $2.60 \mathrm{e}-06$ \\
\hline G0:0004888 & transmembrane signaling receptor activity & 7 of 1226 & $1.17 \mathrm{e}-05$ \\
\hline \multicolumn{4}{|c|}{ Cellular Component (GO) } \\
\hline GO-term & description & count in gene set & false discovery rate \\
\hline GO:0036020 & endolysosome membrane & 5 of 15 & $2.89 e-11$ \\
\hline G0:0045335 & phagocytic vesicle & 6 of 122 & $1.01 e-09$ \\
\hline G0:0032009 & early phagosome & 4 of 9 & $1.01 e-09$ \\
\hline G0:0030139 & endocytic vesicle & 7 of 275 & $1.01 e-09$ \\
\hline \multirow[t]{2}{*}{ GO:0044433 } & cytoplasmic vesicle part & 9 of 1447 & $5.27 e-08$ \\
\hline & & & (more ...) \\
\hline
\end{tabular}

Figure 8. Functional enrichments and Statistics of TLR networks interactions and association. Gene Ontology (GO) is used to perform enrichment analysis for biological process, molecular functions and cellular components.

\section{Materials and methods}

\subsection{Adipose Tissue Collection}

Human adipose tissue (waste material) is collected after obtaining informed consent from donors undergoing elective liposuction in cooperation with the Department of Plastic Surgery of the UZ-Brussels (Brussels, Belgium) and the ATLAS clinic (Brussels, Belgium).

\subsection{Isolation and Culture of MSCs}

The isolation and culture procedure can be briefly explained as follows: $125 \mathrm{~mL}$ of liposuction material is extensively washed (centrifugation $3 \mathrm{~min}$ at $600 \times g$ ) with equal volumes of phosphate-buffered saline (PBS) (Sigma-Aldrich, Diegem, Belgium) to remove erythrocytes. The adipose tissue material is incubated for $45 \mathrm{~min}$ at $37^{\circ} \mathrm{C}$ with dissociation buffer (1:1). This solution is composed of $1 \%(v / v)$ bovine serum albumin (BSA) (Sigma-Aldrich, Diegem, Belgium) and $1 \mathrm{mg} / \mathrm{mL}$ collagenase A (Roche Applied Science, Vilvoorde, Belgium) dissolved in PBS. After this digestion step, the sample is passed through a mesh filter to remove connective tissue debris. Subsequently, the filtrate is washed by centrifugation $\left(10 \min 4{ }^{\circ} \mathrm{C}\right.$ at $\left.600 \times g\right)$ and the supernatant removed. The recovered pellet is suspended in $50 \mathrm{~mL}$ PBS supplemented with $1 \%(v / v)$ BSA and centrifuged again for $10 \mathrm{~min}$ at $600 \times g\left(4^{\circ} \mathrm{C}\right)$. The new pellet is resuspended in $30 \mathrm{~mL}$ of PBS, supplemented with $1 \%(v / v)$ BSA. The resulting cell suspension is carefully brought on top of $15 \mathrm{~mL}$ of Ficoll gradient solution (Sigma-Aldrich, Diegem, Belgium) and 
centrifuged for $20 \mathrm{~min}$ at $1000 \times g\left(4^{\circ} \mathrm{C}\right)$. Upon centrifugation, the upper layer is removed and the cell interface layer is carefully collected in $50 \mathrm{~mL}$ PBS supplemented with $1 \%(v / v)$ BSA. The cell suspension is centrifuged for $10 \mathrm{~min}$ at $600 \times g\left(8^{\circ} \mathrm{C}\right)$ and the supernatant is removed. The cell pellet is cultured in a $58 \mathrm{~cm}^{2}$ petri dish (Greiner Bio One, Vilvoorde, Belgium) in Dulbecco's Modified Eagle Medium (Lonza, Braine-1'Alleud, Belgium) with Low-Glucose, L-glutamine, Sodium Pyrovate, Phenol Red but no HEPES. This medium was then supplemented with $10 \%$ $(v / v)$ fetal bovine serum (HyClone, Perbio Science, Erembodegem-Aalst, Belgium), $7.33 \mathrm{IU} / \mathrm{mL}$ benzyl penicillin (Continental Pharma, Brussels, Belgium), $50 \mu \mathrm{g} / \mathrm{mL}$ streptomycin sulphate (Sigma-Aldrich, Diegem, Belgium), $2.5 \mu \mathrm{g} / \mathrm{mL}$ Fungizone (Invitrogen, Merelbeke, Belgium). After 5 days of culture at $37{ }^{\circ} \mathrm{C}$, under an atmosphere of $5 \% \mathrm{CO}_{2}$ and $95 \%$ air, non-adherent cells are removed by replacing the medium. During the culture period, the medium is changed once a week. When the culture reaches sub-confluence $(80 \%)$, the cells are harvested using TrypLE Select (Sigma-Aldrich, Diegem, Belgium) and counted using a $0.4 \%(w / v)$ trypan blue dye solution (Sigma-Aldrich, Diegem, Belgium). For further cell-expansion, cells are replated at a low-density of 1000 cells $/ \mathrm{cm}^{2}$ followed by passage every time those cells reached subconfluence. Primo-culture (PM), early-passage (passage 1 2) and late-passage (passage 3 4) of MSCs were evaluated. The morphology of MSCs is observed by light microscopy.

\subsection{The Culture Characteristics of Adipose MSCs}

During their expansion (from PM until P4), the number of MSCs generated when the cultures reached the sub-confluency, was evaluated as a function of culture time by Trypan blue exclusion assay (Lonza, Braine- $1^{\prime}$ Alleud, Belgium). Therefore, the cumulative cell number at each passage was calculated as a ratio of total number of cells harvested to total number of cells seeded multiplied by the total number of cells from the previous passage.

During their expansion (from PM until P4), MSCs were assessed for their expression of SA $\beta$-Galactosidase (SA-B-Gal) which is a common marker of senescence. MSCs cells were plated in a 48 well-plate for $24 \mathrm{~h}$ before staining cells with the Senescence Detection Kit (BioVision, Milpitas, CA, USA). SA-B-Gal catalyzes the hydrolysis of X-gal, which produces a blue color in senescent cells. The number of blue MSCs out of 100 total cells was therefore scored using an inverted microscope. The results were presented as the mean percentage ( \pm SEM) of SA $\beta$-Gal positive cells compared to total counted cells.

\subsection{Phenotype of MSCs}

The cells isolated from the adipose cultures are characterized for the expression of a panel of markers (Table 1). This screening is performed by flow cytometry using fluorochrome labeled monoclonal antibodies.

Table 1. List of Antibodies.

\begin{tabular}{cccc}
\hline Primary Antibody & Company & Species & Dilution \\
\hline CD34-PC5 & BD & mouse & $1 / 20$ \\
\hline CD73-PE & BD & mouse & $1 / 20$ \\
\hline CD90-APC & BL & mouse & $1 / 20$ \\
\hline CD105-FITC & AC & mouse & $1 / 20$ \\
\hline CD45-PE & BD & mouse & $1 / 20$ \\
\hline CD14-PE & BD & mouse & $1 / 20$ \\
\hline CD19-PE & BD & mouse & $1 / 20$ \\
\hline HLA-DR-PerCP & BD & mouse & $1 / 20$ \\
\hline
\end{tabular}

\subsection{In Vitro Lineage Differentiation of MSCs}

The cells isolated from the adipose cultures are investigated for their lineage differentiation capacities. 


\subsubsection{Osteogenesis}

Cells recovered from the cultures, were cultivated in osteogenesis differentiation medium consisting of $90 \%(v / v)$ STEMPRO ${ }^{\circledR}$ Osteocyte/Chondrocyte Differentiation Basal Medium and 10\% $(v / v)$ STEMPRO ${ }^{\circledR}$ Osteogenesis Supplement (all from Gibco, Life Technologies, Merelbeke, Belgium) for 3 weeks. The medium was changed every 2 days. To confirm the osteogenic differentiation, cells were fixed with $4 \%(w / v)$ paraformaldehyde (PFA) during $30 \mathrm{~min}$ at room temperature (RT). After fixation, the wells were rinsed twice with distilled water. Next, the cells were stained with $2 \%(w / v)$ Alizarin Red S (pH 4.2) solution (Sigma, Bornem, Belgium) for $30 \mathrm{~min}$ at RT. Finally, wells were rinsed three times with distilled water and visualized with a phase contrast microscope (Nikon).

\subsubsection{Adipogenesis}

Cells recovered from the cultures, were cultivated in adipogenesis differentiation medium consisting of $90 \%(v / v)$ STEMPRO ${ }^{\circledR}$ Adipocyte Differentiation Basal Medium and $10 \%(v / v)$ STEMPRO $^{\circledR}$ Adipogenesis Supplement (all from Gibco, Life Technologies, Merelbeke, Belgium) for 2 weeks. The medium was changed every 2 days. To confirm the adipogenic differentiation, cells were fixed with $4 \%(w / v)$ PFA during $30 \mathrm{~min}$ at RT. Following fixation, the wells were rinsed twice with PBS and the cells stained with $0.5 \%(v / v)$ Oil Red O in isopropanol (Sigma, Bornem, Belgium) for $30 \mathrm{~min}$ at RT. Finally, wells were rinsed three times with distilled water and visualized with a phase contrast microscope (Nikon).

\subsection{Inflammatory Stimulation}

MSCs were incubated for $18 \mathrm{~h}$ with a pro-inflammatory cytokine cocktail. The cocktail used to stimulate the cells is composed of four cytokines including $25 \mathrm{ng} / \mathrm{mL}$ interleukin (IL)-1 $\beta$ (Peprotech, Rocky Hill, NJ, USA), $50 \mathrm{ng} / \mathrm{mL}$ tumor necrosis factor (TNF)- $\alpha$, $10 \mathrm{ng} / \mathrm{mL}$ interferon (IFN)- $\alpha$ and $50 \mathrm{ng} / \mathrm{mL}$ IFN- $\gamma$ (all from Prospec Inc., Rehovot, Israel). This cocktail of cytokines was used in each experiment requiring an inflammatory stimulation.

\subsection{Transcriptional Profile of MSCs}

The transcriptional profile of TLR, cytokine and regulatory mediators by MSCs was determined by quantitative polymerase chain reaction (qPCR) as previously performed [79-81]. Total mRNA was extracted using the TriPure Isolation Reagent ${ }^{\mathrm{TM}}$ (Roche Applied Science) and quantified at $260 \mathrm{~nm}$ using a Nanodrop ${ }^{\mathrm{TM}}$ spectrophotometer (Thermo Scientific, Waltham, MA, USA). Total RNA was reverse transcribed into cDNA using iScript ${ }^{\mathrm{TM}}$ cDNA Synthesis Kit (BioRad, Nazareth, Belgium) followed by cDNA purification with the GenElute PCR clean up kit (Sigma-Aldrich) according to the manufacturer's instructions. cDNA products were used for quantitative amplification of the target genes. The gene expression assays used in this study are listed in Table 2. All samples were done in duplicate and each run included two no template controls and a serial dilution of a pooled cDNA mix from all samples to estimate the qPCR efficiency. The qPCR reaction mix consisted of $10 \mu \mathrm{L}$ TaqMan Fast Advanced Master Mix (Life Technologies), $1 \mu \mathrm{L} 20 \times$ Assay-on-Demand Mix (Life Technologies) and $2 \mu \mathrm{L}$ of cDNA in a $20 \mu \mathrm{L}$ volume adjusted with DNase/RNase-free water. qPCR conditions, using the StepOne Plus system (Life Technologies), were as follows: incubation for $20 \mathrm{~s}$ at $95^{\circ} \mathrm{C}$, followed by 40 cycles of $1 \mathrm{~s}$ denaturation at $95^{\circ} \mathrm{C}$, annealing for $20 \mathrm{~s}$ at $60^{\circ} \mathrm{C}$ (Life Technologies). qPCR efficiency was estimated by the StepOne Plus System's Software and the data were only used when the calculated PCR efficiency ranged from 0.85-1.15. Moreover, for selecting reliable reference genes to normalize the qPCR data, we first evaluated the expression stability of five candidate reference genes: glyceraldehyde 3-phosphate dehydrogenase (GAPDH), beta-2-microglobulin (B2M), hydroxy-methylbilane synthase (HMBS), beta-actin (ACTB) and ubiquitin C (UBC). According to geNorm ${ }^{\circledR}$ (Biogazelle, Gent, Belgium), the optimal number of reference targets to be used in this experiment was $2(\mathrm{~V}<0.15)$. As such, ACTB and GAPDH were selected as the most stable reference genes in all samples using qbasePLUS ${ }^{\circledR}$ software $\left(\right.$ geNorm $\left.^{\circledR}\right)$. Relative 
mRNA expression levels of the target genes in AT-MSCs were thus normalized against the geometric means of both reference gene mRNAs.

Table 2. Taqman Gene Expression Assays.

\begin{tabular}{|c|c|c|c|}
\hline Genes & $\begin{array}{c}\text { Assay-on-Demand } \\
\text { ID }\end{array}$ & $\begin{array}{l}\text { Amplicon Length } \\
\text { (bp) }\end{array}$ & Supplier \\
\hline \multicolumn{4}{|c|}{ Housekeeping } \\
\hline GAPDH & Hs99999905_m1 & 122 & $\mathrm{AB}$ \\
\hline B2M & Hs99999907_m1 & 75 & $\mathrm{AB}$ \\
\hline HMBS & Hs00609296_g1 & 69 & $\mathrm{AB}$ \\
\hline ACTB & Hs99999903_m1 & 171 & $\mathrm{AB}$ \\
\hline UBC & Hs00824723_m1 & 71 & $\mathrm{AB}$ \\
\hline \multicolumn{4}{|l|}{ Cytokines } \\
\hline IL-6 & Hs00174131_m1 & 95 & $\mathrm{AB}$ \\
\hline IL-8 & Hs00174103_m1 & 101 & $\mathrm{AB}$ \\
\hline IL-1b & Hs01555410_m1 & 91 & $\mathrm{AB}$ \\
\hline CCL5 & Hs00982282_m1 & 70 & $\mathrm{AB}$ \\
\hline IL-1Ra & Hs00991010_m1 & 97 & $\mathrm{AB}$ \\
\hline TNF- $\alpha$ & Hs00174128_m1 & 80 & $\mathrm{AB}$ \\
\hline \multicolumn{4}{|l|}{ TLR } \\
\hline TLR-1 & Hs00413978_m1 & 72 & $\mathrm{AB}$ \\
\hline TLR-2 & Hs02621280_s1 & 112 & $\mathrm{AB}$ \\
\hline TLR-3 & Hs01551079_g1 & 144 & $\mathrm{AB}$ \\
\hline TLR-4 & Hs00152939_m1 & 89 & $\mathrm{AB}$ \\
\hline TLR-5 & Hs01920773_s1 & 89 & $\mathrm{AB}$ \\
\hline TLR-6 & Hs01039989_s1 & 79 & $\mathrm{AB}$ \\
\hline TLR-7 & Hs01933259_s1 & 121 & $\mathrm{AB}$ \\
\hline TLR-8 & Hs00152972_m1 & 89 & $\mathrm{AB}$ \\
\hline TLR-9 & Hs00370913_s1 & 70 & $\mathrm{AB}$ \\
\hline TLR-10 & Hs01935337_s1 & 153 & $\mathrm{AB}$ \\
\hline \multicolumn{4}{|l|}{ Regulatory } \\
\hline HGF & Hs00300159_m1 & 92 & $\mathrm{AB}$ \\
\hline HLA-G & Hs00365950_g1 & 91 & $\mathrm{AB}$ \\
\hline HMOX1 & Hs01110250_m1 & 82 & $\mathrm{AB}$ \\
\hline IDO1 & Hs00984148_m1 & 66 & $\mathrm{AB}$ \\
\hline IDO2 & Hs01589373_m1 & 101 & $\mathrm{AB}$ \\
\hline IGFBP2 & Hs01040719_m1 & 54 & $\mathrm{AB}$ \\
\hline IGFBP3 & Hs00181211_m1 & 78 & $\mathrm{AB}$ \\
\hline LIF & Hs00171455_m1 & 66 & $\mathrm{AB}$ \\
\hline PTGS1 & Hs00377726_m1 & 60 & $\mathrm{AB}$ \\
\hline PTGS2 & Hs00153133_m1 & 75 & $\mathrm{AB}$ \\
\hline TGFB1 & Hs00998133_m1 & 57 & $\mathrm{AB}$ \\
\hline
\end{tabular}




\subsection{Construction and Analysis of the Protein-Protein Interaction Network}

The PPI network was predicted using the Search Tool for the Retrieval of Interacting Genes (STRING) online data-base (http:/ / string-db.org; version 11.0) (Accessed on 10 March 2021). The STRING database (relies on many data sources) was used also for the functional annotation and pathway enrichment analysis.

\subsection{Statistical Analysis}

The results are expressed as the mean \pm standard error of the mean (SEM) from 7 different donor samples. Each sample for each condition was analyzed in triplicate. For statistical comparison, the unpaired $t$-test is performed. A $p$-value less than 0.05 is considered statistically significant (Prism, Graph-Pad Software, La Jolla, CA, USA).

\section{Conclusions}

AT-MSCs promote immunomodulation and tissue repair through different signaling pathways. They act by sensing the tissue environment as well as by modulating the features of local immune and progenitor cells. The current study describes, for the first time, the impact of the combination of inflammation and cell-expansion (two critical signals within the tissue site) on the sensitivity and responsiveness of AT-MSCs by exploring the transcriptional characteristics of some trophic and regulatory gene. AT-MSCs maintained a long-term expansion level in our cell culture setting, without significant sign of senescence. Senescence and viability should be evaluated during the expansion of AT-MSCs to guarantee the quality of the preparation. Regarding the therapeutic profile of AT-MSCs, several cytokines, chemokines, regulatory factors and TLRs, described as important for their immuno-reparative potential, were differentially expressed and modulated. Such observations are encouraging and have to be extended to further define these gene differences on a protein level. Setting up such an assay may be useful as a distinct protein profile can be obtained. Inflammation may thus increase the sensitivity and responsiveness of MSCs to their surroundings by at least three means (i) upregulating their pattern of TLRs that act as sentinels of infection and injury/damage; (ii) inducing a shift in their cytokine profile which contribute to the homing and activation of immune cells with a proreparative and anti-inflammatory phenotype; (iii) triggering the expression of regulatory and protective mediators to guarantee tissue homeostasis. Depending on their expression, modulation and role, these cytokines, chemokine, regulatory mediators and TLR may represent appropriate targets (on/off switch strategy to increase or decrease a pathway) to improve the therapeutic efficiency of AT-MSCs or a relevant set of biomarkers that indicate the potential efficiency of AT-MSCs. A defined transcriptomic signature would support the identification of sub-populations of AT-MSCs with a specific immuno-trophic profile suitable for immunomodulation and tissue repair. Such observations may strength our knowledge about the influence of tissue surrounding signals such as inflammation and proliferation that may improve or hamper the tissue healing process of MSCs. However, we have to keep in mind that the in vivo condition might be different as these findings are obtained from in vitro experiments. It is important to point out that most biological properties of MSCs are derived from studies with cells expanded ex vivo, rather than in vivo research. For the in vivo investigation of MSCs, different animal models are widely used, but this is not sufficient to properly reflect what is happening in the human body. It is conceivable that in a near future, the details about the in vivo interplay between AT-MSCs and their environment as well as their collective actions during tissue repair, will accelerate the progress in the field regenerative medicine. Hence, feasible approaches are needed for monitoring the inflammatory and immunological status of patients at the time therapeutic cells are infused to help optimize cell-based therapy. Indeed, further investigations in the effects of inflammatory factors, which fluctuate considerably in the microenvironment of a tissue lesion, on the immuno-biology of stem cells will accelerate the development of novel therapeutic approaches. Collectively, these discussions, reflections and perspectives 
should increase the knowledge regarding the therapeutic value of AT-MSCs and hopefully be clinically relevant.

Author Contributions: Conceptualization, M.M., K.B., D.D., R.M.R., J.D.K. and M.N.; investigation, M.M., K.B., D.D., R.M.R., R.M. and M.N; resources, M.M., P.L., T.V., H.F., V.R. and L.L.; writingoriginal draft preparation, M.M., K.B., D.D., H.F., J.D.K. and M.N.; review and editing, M.N., D.D., R.M.; supervision, M.N. and J.D.K.; project administration, J.D.K. and M.N.; funding acquisition, M.M., P.L., T.V., H.F., V.R. and L.L. All authors have read and agreed to the published version of the manuscript.

Funding: This research has received funding from grants of Generations For Life Foundation, the Scientific Research Foundation Flanders (FWO), Le Fonds National de la Recherche Scientifique (FRSM, Télévie), Research Project (PDR) grant (35036908), Les Amis de l'Institut Bordet, the Arthritis Society (SOG-20-0000000046), the Canadian Institutes of Health Research (PTJ175110), the Research Council (OZR) of the Vrije Universiteit Brussel (VUB) and the Inter-university Attraction Pole programme of the Belgian Science Policy Office (IAP-HEPRO BELSPO).

Institutional Review Board Statement: The samples were collected after approval by the local ethics committee of Institut Jules Bordet (CE2387; 9 March 2015) and according to the recognized guidelines of the Helsinki Declaration.

Informed Consent Statement: Informed written consent was obtained for all donors.

Data Availability Statement: The data presented in this study might be available depending on the type of the demand and the use and are linked to the authorities' authorization. A request must be sent to the corresponding author with the permission of all authors.

Acknowledgments: The authors thank Patrick Wilikins and Jan Heiremans (ATLAS clinic) for the kind donation of human adipose tissue samples upon informed consent of the involved patients. We would like to thank the Cell Therapy Unit team for their helpful discussions.

Conflicts of Interest: The authors have no conflict of interest to declare. They confirm that there are no conflicts of interest associated with this publication. The manuscript has been read and approved by all named authors.

$\begin{array}{ll}\text { Abbreviations } \\ \text { CCL } & \text { chemokine ligand } \\ \text { HGF } & \text { hepatocyte growth factor } \\ \text { HLA } & \text { human leukocyte antigen } \\ \text { HMOX } & \text { heme oxygenase } \\ \text { IDO } & \text { indoleamine 2.3-dioxygenase } \\ \text { IGFBP } & \text { insulin-like growth factor binding-protein } \\ \text { IL } & \text { interleukin } \\ \text { LIF } & \text { leukemia inhibitory factor } \\ \text { MSCs } & \text { mesenchymal stromal cells } \\ \text { P } & \text { passage } \\ \text { PM } & \text { primo culture } \\ \text { PTGS } & \text { prostaglandin endoperoxide synthase } \\ \text { SEM } & \text { standard error of the mean } \\ \text { TGF } & \text { transforming growth factor } \\ \text { TLR } & \text { Toll-like receptor } \\ \text { TNF } & \text { tumor necrosis factor }\end{array}$

\section{References}

1. Najar, M.; Bouhtit, F.; Melki, R.; Afif, H.; Hamal, A.; Fahmi, H.; Merimi, M.; Lagneaux, L. Mesenchymal Stromal Cell-Based Therapy: New Perspectives and Challenges. J. Clin. Med. 2019, 8, 626. [CrossRef]

2. Andrzejewska, A.; Lukomska, B.; Janowski, M. Concise Review: Mesenchymal Stem Cells: From Roots to Boost. Stem Cells 2019, 37, 855-864. [CrossRef]

3. Poggi, A.; Zocchi, M.R. Immunomodulatory Properties of Mesenchymal Stromal Cells: Still Unresolved "Yin and Yang". Curr. Stem Cell Res. Ther. 2019, 14, 344-350. [CrossRef] 
4. Bobyleva, P.; Gornostaeva, A.; Andreeva, E.; Ezdakova, M.; Gogiya, B.; Buravkova, L. Reciprocal modulation of cell functions upon direct interaction of adipose mesenchymal stromal and activated immune cells. Cell Biochem. Funct. 2019, 37, 228-238. [CrossRef] [PubMed]

5. Wang, M.; Yuan, Q.; Xie, L. Mesenchymal Stem Cell-Based Immunomodulation: Properties and Clinical Application. Stem Cells Int. 2018, 2018, 3057624. [CrossRef]

6. Kolaparthy, L.K.; Sanivarapu, S.; Moogla, S.; Kutcham, R.S. Adipose Tissue-Adequate, Accessible Regenerative Material. Int. J. Stem Cells 2015, 8, 121-127. [CrossRef]

7. Dominici, M.; Le Blanc, K.; Mueller, I.; Slaper-Cortenbach, I.; Marini, F.; Krause, D.; Deans, R.; Keating, A.; Prockop, D.; Horwitz, E. Minimal criteria for defining multipotent mesenchymal stromal cells. The International Society for Cellular Therapy position statement. Cytotherapy 2006, 8, 315-317. [CrossRef] [PubMed]

8. Praveen Kumar, L.; Kandoi, S.; Misra, R.; Vijayalakshmi, S.; Rajagopal, K.; Verma, R.S. The mesenchymal stem cell secretome: A new paradigm towards cell-free therapeutic mode in regenerative medicine. Cytokine Growth Factor Rev. 2019, 46, 1-9. [CrossRef]

9. Roh, J.S.; Sohn, D.H. Damage-Associated Molecular Patterns in Inflammatory Diseases. Immune Netw. 2018, 18, e27. [CrossRef] [PubMed]

10. Karin, M.; Clevers, H. Reparative inflammation takes charge of tissue regeneration. Nature 2016, 529, 307-315. [CrossRef]

11. Lombardo, E.; DelaRosa, O.; Mancheno-Corvo, P.; Menta, R.; Ramirez, C.; Buscher, D. Toll-like receptor-mediated signaling in human adipose-derived stem cells: Implications for immunogenicity and immunosuppressive potential. Tissue Eng. Part A 2009, 15, 1579-1589. [CrossRef]

12. Delarosa, O.; Dalemans, W.; Lombardo, E. Toll-like receptors as modulators of mesenchymal stem cells. Front. Immunol. 2012, 3, 182. [CrossRef]

13. Caplan, A.I. MSCs: The Sentinel and Safe-Guards of Injury. J. Cell Physiol. 2016, 231, 1413-1416. [CrossRef] [PubMed]

14. Wiese, D.M.; Braid, L.R. Transcriptome profiles acquired during cell expansion and licensing validate mesenchymal stromal cell lineage genes. Stem Cell Res. Ther. 2020, 11, 357. [CrossRef] [PubMed]

15. Busser, H.; De Bruyn, C.; Urbain, F.; Najar, M.; Pieters, K.; Raicevic, G.; Meuleman, N.; Bron, D.; Lagneaux, L. Isolation of adipose-derived stromal cells without enzymatic treatment: Expansion, phenotypical, and functional characterization. Stem Cells Dev. 2014, 23, 2390-2400. [CrossRef] [PubMed]

16. Schneider, S.; Unger, M.; van Griensven, M.; Balmayor, E.R. Adipose-derived mesenchymal stem cells from liposuction and resected fat are feasible sources for regenerative medicine. Eur. J. Med. Res. 2017, 22, 17. [CrossRef] [PubMed]

17. Sharpe, M.E.; Morton, D.; Rossi, A. Nonclinical safety strategies for stem cell therapies. Toxicol. Appl. Pharmacol. 2012, 262, 223-231. [CrossRef]

18. Patrikoski, M.; Sivula, J.; Huhtala, H.; Helminen, M.; Salo, F.; Mannerstrom, B.; Miettinen, S. Different culture conditions modulate the immunological properties of adipose stem cells. Stem Cells Transl. Med. 2014, 3, 1220-1230. [CrossRef]

19. Burrow, K.L.; Hoyland, J.A.; Richardson, S.M. Human Adipose-Derived Stem Cells Exhibit Enhanced Proliferative Capacity and Retain Multipotency Longer Than Donor-Matched Bone Marrow Mesenchymal Stem Cells During Expansion In Vitro. Stem Cells Int. 2017, 2017, 2541275. [CrossRef]

20. Capasso, S.; Alessio, N.; Squillaro, T.; Di Bernardo, G.; Melone, M.A.; Cipollaro, M.; Peluso, G.; Galderisi, U. Changes in Autophagy, Proteasome Activity and Metabolism to Determine a Specific Signature for Acute and Chronic Senescent Mesenchymal Stromal Cells. Oncotarget 2015, 6, 39457-39468. [CrossRef]

21. Ayala-Cuellar, A.P.; Kang, J.H.; Jeung, E.B.; Choi, K.C. Roles of Mesenchymal Stem Cells in Tissue Regeneration and Immunomodulation. Biomol. Ther. 2019, 27, 25-33. [CrossRef] [PubMed]

22. Fayyad-Kazan, H.; Faour, W.H.; Badran, B.; Lagneaux, L.; Najar, M. The immunomodulatory properties of human bone marrowderived mesenchymal stromal cells are defined according to multiple immunobiological criteria. Inflamm. Res. 2016, 65, 501-510. [CrossRef]

23. Wood, K.J.; Issa, F.; Hester, J. Understanding Stem Cell Immunogenicity in Therapeutic Applications. Trends Immunol. 2016, 37, 5-16. [CrossRef]

24. Charron, D.; Suberbielle-Boissel, C.; Al-Daccak, R. Immunogenicity and allogenicity: A challenge of stem cell therapy. J. Cardiovasc. Transl. Res. 2009, 2, 130-138. [CrossRef] [PubMed]

25. Moraes, D.A.; Sibov, T.T.; Pavon, L.F.; Alvim, P.Q.; Bonadio, R.S.; Da Silva, J.R.; Pic-Taylor, A.; Toledo, O.A.; Marti, L.C.; Azevedo, R.B.; et al. A reduction in CD90 (THY-1) expression results in increased differentiation of mesenchymal stromal cells. Stem Cell Res. Ther. 2016, 7, 97. [CrossRef]

26. Anderson, P.; Carrillo-Galvez, A.B.; Garcia-Perez, A.; Cobo, M.; Martin, F. CD105 (endoglin)-negative murine mesenchymal stromal cells define a new multipotent subpopulation with distinct differentiation and immunomodulatory capacities. PLoS ONE 2013, 8, e76979. [CrossRef]

27. Busser, H.; Najar, M.; Raicevic, G.; Pieters, K.; Velez Pombo, R.; Philippart, P.; Meuleman, N.; Bron, D.; Lagneaux, L. Isolation and Characterization of Human Mesenchymal Stromal Cell Subpopulations: Comparison of Bone Marrow and Adipose Tissue. Stem Cells Dev. 2015, 24, 2142-2157. [CrossRef]

28. Najar, M.; Rodrigues, R.M.; Buyl, K.; Branson, S.; Vanhaecke, T.; Lagneaux, L.; Rogiers, V.; De Kock, J. Proliferative and phenotypical characteristics of human adipose tissue-derived stem cells: Comparison of Ficoll gradient centrifugation and red blood cell lysis buffer treatment purification methods. Cytotherapy 2014, 16, 1220-1228. [CrossRef] [PubMed] 
29. Lin, C.S.; Ning, H.; Lin, G.; Lue, T.F. Is CD34 truly a negative marker for mesenchymal stromal cells? Cytotherapy 2012, 14, 1159-1163. [CrossRef]

30. Bourin, P.; Bunnell, B.A.; Casteilla, L.; Dominici, M.; Katz, A.J.; March, K.L.; Redl, H.; Rubin, J.P.; Yoshimura, K.; Gimble, J.M. Stromal cells from the adipose tissue-derived stromal vascular fraction and culture expanded adipose tissue-derived stromal/stem cells: A joint statement of the International Federation for Adipose Therapeutics and Science (IFATS) and the International Society for Cellular Therapy (ISCT). Cytotherapy 2013, 15, 641-648. [CrossRef]

31. Sidney, L.E.; Branch, M.J.; Dunphy, S.E.; Dua, H.S.; Hopkinson, A. Concise review: Evidence for CD34 as a common marker for diverse progenitors. Stem Cells 2014, 32, 1380-1389. [CrossRef]

32. Togarrati, P.P.; Sasaki, R.T.; Abdel-Mohsen, M.; Dinglasan, N.; Deng, X.; Desai, S.; Emmerson, E.; Yee, E.; Ryan, W.R.; da Silva, M.C.P.; et al. Identification and characterization of a rich population of CD34(+) mesenchymal stem/stromal cells in human parotid, sublingual and submandibular glands. Sci. Rep. 2017, 7, 3484. [CrossRef] [PubMed]

33. Alekseenko, L.L.; Shilina, M.A.; Lyublinskaya, O.G.; Kornienko, J.S.; Anatskaya, O.V.; Vinogradov, A.E.; Grinchuk, T.M.; Fridlyanskaya, I.I.; Nikolsky, N.N. Quiescent Human Mesenchymal Stem Cells Are More Resistant to Heat Stress than Cycling Cells. Stem Cells Int. 2018, 2018, 3753547. [CrossRef] [PubMed]

34. Lefevre, C.; Chartoire, D.; Ferraz, J.C.; Verdier, T.; Pinteur, C.; Chanon, S.; Pesenti, S.; Vieille-Marchiset, A.; Genestier, L.; Vidal, H.; et al. Obesity activates immunomodulating properties of mesenchymal stem cells in adipose tissue with differences between localizations. FASEB J. 2021, 35, e21650. [CrossRef] [PubMed]

35. Chavakis, E.; Urbich, C.; Dimmeler, S. Homing and engraftment of progenitor cells: A prerequisite for cell therapy. J. Mol. Cell. Cardiol. 2008, 45, 514-522. [CrossRef] [PubMed]

36. Serra, M.B.; Barroso, W.A.; da Silva, N.N.; Silva, S.D.N.; Borges, A.C.R.; Abreu, I.C.; Borges, M. From Inflammation to Current and Alternative Therapies Involved in Wound Healing. Int. J. Inflam 2017, 2017, 3406215. [CrossRef]

37. Beland, S.; Desy, O.; Vallin, P.; Basoni, C.; De Serres, S.A. Innate immunity in solid organ transplantation: An update and therapeutic opportunities. Expert Rev. Clin. Immunol. 2015, 11, 377-389. [CrossRef]

38. Julier, Z.; Park, A.J.; Briquez, P.S.; Martino, M.M. Promoting tissue regeneration by modulating the immune system. Acta Biomater. 2017, 53, 13-28. [CrossRef]

39. Glass, G.E.; Chan, J.K.; Freidin, A.; Feldmann, M.; Horwood, N.J.; Nanchahal, J. TNF-alpha promotes fracture repair by augmenting the recruitment and differentiation of muscle-derived stromal cells. Proc. Natl. Acad. Sci. USA 2011, 108, 1585-1590. [CrossRef]

40. Lee, E.G.; Luckett-Chastain, L.R.; Calhoun, K.N.; Frempah, B.; Bastian, A.; Gallucci, R.M. Interleukin 6 Function in the Skin and Isolated Keratinocytes Is Modulated by Hyperglycemia. J. Immunol. Res. 2019, 2019, 5087847. [CrossRef]

41. Li, P.; Li, S.H.; Wu, J.; Zang, W.F.; Dhingra, S.; Sun, L.; Weisel, R.D.; Li, R.K. Interleukin-6 downregulation with mesenchymal stem cell differentiation results in loss of immunoprivilege. J. Cell. Mol. Med. 2013, 17, 1136-1145. [CrossRef] [PubMed]

42. Shi, Y.; Cao, J.; Wang, Y. Rethinking regeneration: Empowerment of stem cells by inflammation. Cell Death Differ. 2015, 22, 1891-1892. [CrossRef] [PubMed]

43. Najar, M.; Raicevic, G.; Fayyad-Kazan, H.; De Bruyn, C.; Bron, D.; Toungouz, M.; Lagneaux, L. Impact of different mesenchymal stromal cell types on T-cell activation, proliferation and migration. Int. Immunopharmacol. 2013, 15, 693-702. [CrossRef] [PubMed]

44. Harrell, C.R.; Markovic, B.S.; Fellabaum, C.; Arsenijevic, N.; Djonov, V.; Volarevic, V. The role of Interleukin 1 receptor antagonist in mesenchymal stem cell-based tissue repair and regeneration. Biofactors 2020, 46, 263-275. [CrossRef]

45. Zhang, J.M.; An, J. Cytokines, inflammation, and pain. Int. Anesthesiol. Clin. 2007, 45, 27-37. [CrossRef] [PubMed]

46. Bouchery, T.; Harris, N. Neutrophil-macrophage cooperation and its impact on tissue repair. Immunol. Cell Biol. 2019, 97, 289-298. [CrossRef] [PubMed]

47. Galun, E.; Rose-John, S. The regenerative activity of interleukin-6. Methods Mol. Biol. 2013, 982, 59-77. [CrossRef]

48. Neuss, S.; Becher, E.; Woltje, M.; Tietze, L.; Jahnen-Dechent, W. Functional expression of HGF and HGF receptor/c-met in adult human mesenchymal stem cells suggests a role in cell mobilization, tissue repair, and wound healing. Stem Cells 2004, 22, 405-414. [CrossRef]

49. Choi, W.; Lee, J.; Lee, J.; Lee, S.H.; Kim, S. Hepatocyte Growth Factor Regulates Macrophage Transition to the M2 Phenotype and Promotes Murine Skeletal Muscle Regeneration. Front. Physiol. 2019, 10, 914. [CrossRef]

50. Hubel, J.; Hieronymus, T. HGF/Met-Signaling Contributes to Immune Regulation by Modulating Tolerogenic and Motogenic Properties of Dendritic Cells. Biomedicines 2015, 3, 138-148. [CrossRef]

51. Agarwal, A.; Bolisetty, S. Adaptive responses to tissue injury: Role of heme oxygenase-1. Trans. Am. Clin. Climatol. Assoc. 2013, 124, 111-122. [PubMed]

52. Mougiakakos, D.; Jitschin, R.; Johansson, C.C.; Okita, R.; Kiessling, R.; Le Blanc, K. The impact of inflammatory licensing on heme oxygenase-1-mediated induction of regulatory T cells by human mesenchymal stem cells. Blood 2011, 117, 4826-4835. [CrossRef] [PubMed]

53. Rodriguez, L.A., II; Mohammadipoor, A.; Alvarado, L.; Kamucheka, R.M.; Asher, A.M.; Cancio, L.C.; Antebi, B. Preconditioning in an Inflammatory Milieu Augments the Immunotherapeutic Function of Mesenchymal Stromal Cells. Cells 2019, 8, 462. [CrossRef] [PubMed]

54. Najar, M.; Raicevic, G.; Crompot, E.; Fayyad-Kazan, H.; Bron, D.; Toungouz, M.; Lagneaux, L. The Immunomodulatory Potential of Mesenchymal Stromal Cells: A Story of a Regulatory Network. J. Immunother. 2016, 39, 45-59. [CrossRef] 
55. Zhang, Q.; Shi, S.; Liu, Y.; Uyanne, J.; Shi, Y.; Shi, S.; Le, A.D. Mesenchymal stem cells derived from human gingiva are capable of immunomodulatory functions and ameliorate inflammation-related tissue destruction in experimental colitis. J. Immunol. 2009, 183, 7787-7798. [CrossRef]

56. Mellor, A.L.; Lemos, H.; Huang, L. Indoleamine 2,3-Dioxygenase and Tolerance: Where Are We Now? Front Immunol. 2017, 8 , 1360. [CrossRef]

57. Zhang, S.; Liu, Y.; Zhang, X.; Zhu, D.; Qi, X.; Cao, X.; Fang, Y.; Che, Y.; Han, Z.C.; He, Z.X.; et al. Prostaglandin E2 hydrogel improves cutaneous wound healing via M2 macrophages polarization. Theranostics 2018, 8, 5348-5361. [CrossRef]

58. Loynes, C.A.; Lee, J.A.; Robertson, A.L.; Steel, M.J.; Ellett, F.; Feng, Y.; Levy, B.D.; Whyte, M.K.B.; Renshaw, S.A. PGE2 production at sites of tissue injury promotes an anti-inflammatory neutrophil phenotype and determines the outcome of inflammation resolution in vivo. Sci. Adv. 2018, 4, eaar8320. [CrossRef]

59. Shirjang, S.; Mansoori, B.; Solali, S.; Hagh, M.F.; Shamsasenjan, K. Toll-like receptors as a key regulator of mesenchymal stem cell function: An up-to-date review. Cell. Immunol. 2017, 315, 1-10. [CrossRef]

60. DelaRosa, O.; Lombardo, E. Modulation of adult mesenchymal stem cells activity by toll-like receptors: Implications on therapeutic potential. Mediat. Inflamm. 2010, 2010, 865601. [CrossRef]

61. Dasu, M.R.; Isseroff, R.R. Toll-like receptors in wound healing: Location, accessibility, and timing. J. Investig. Dermatol. 2012, 132, 1955-1958. [CrossRef] [PubMed]

62. Fawzy El-Sayed, K.M.; Klingebiel, P.; Dorfer, C.E. Toll-like Receptor Expression Profile of Human Dental Pulp Stem/Progenitor Cells. J. Endod. 2016, 42, 413-417. [CrossRef] [PubMed]

63. Kawasaki, T.; Kawai, T. Toll-like receptor signaling pathways. Front. Immunol. 2014, 5, 461. [CrossRef] [PubMed]

64. Hwa Cho, H.; Bae, Y.C.; Jung, J.S. Role of toll-like receptors on human adipose-derived stromal cells. Stem Cells 2006, 24, 2744-2752. [CrossRef] [PubMed]

65. Abarbanell, A.M.; Wang, Y.; Herrmann, J.L.; Weil, B.R.; Poynter, J.A.; Manukyan, M.C.; Meldrum, D.R. Toll-like receptor 2 mediates mesenchymal stem cell-associated myocardial recovery and VEGF production following acute ischemia-reperfusion injury. Am. J. Physiol. Heart Circ. Physiol. 2010, 298, H1529-H1536. [CrossRef] [PubMed]

66. Li, J.; Tan, J.; Martino, M.M.; Lui, K.O. Regulatory T-Cells: Potential Regulator of Tissue Repair and Regeneration. Front. Immunol. 2018, 9, 585. [CrossRef] [PubMed]

67. Schreibelt, G.; Tel, J.; Sliepen, K.H.; Benitez-Ribas, D.; Figdor, C.G.; Adema, G.J.; de Vries, I.J. Toll-like receptor expression and function in human dendritic cell subsets: Implications for dendritic cell-based anti-cancer immunotherapy. Cancer Immunol. Immunother. 2010, 59, 1573-1582. [CrossRef]

68. Turton, H.A.; Thompson, A.A.R.; Farkas, L. RNA Signaling in Pulmonary Arterial Hypertension-A Double-Stranded Sword. Int. J. Mol. Sci. 2020, 21, 3124. [CrossRef]

69. Dumitru, C.A.; Hemeda, H.; Jakob, M.; Lang, S.; Brandau, S. Stimulation of mesenchymal stromal cells (MSCs) via TLR3 reveals a novel mechanism of autocrine priming. FASEB J. 2014, 28, 3856-3866. [CrossRef]

70. Van den Akker, F.; de Jager, S.C.; Sluijter, J.P. Mesenchymal stem cell therapy for cardiac inflammation: Immunomodulatory properties and the influence of toll-like receptors. Mediat. Inflamm. 2013, 2013, 181020. [CrossRef]

71. Tomchuck, S.L.; Zwezdaryk, K.J.; Coffelt, S.B.; Waterman, R.S.; Danka, E.S.; Scandurro, A.B. Toll-like receptors on human mesenchymal stem cells drive their migration and immunomodulating responses. Stem Cells 2008, 26, 99-107. [CrossRef] [PubMed]

72. Yu, S.; Cho, H.H.; Joo, H.J.; Bae, Y.C.; Jung, J.S. Role of MyD88 in TLR agonist-induced functional alterations of human adipose tissue-derived mesenchymal stem cells. Mol. Cell Biochem. 2008, 317, 143-150. [CrossRef] [PubMed]

73. Herzmann, N.; Salamon, A.; Fiedler, T.; Peters, K. Lipopolysaccharide induces proliferation and osteogenic differentiation of adipose-derived mesenchymal stromal cells in vitro via TLR4 activation. Exp. Cell Res. 2017, 350, 115-122. [CrossRef]

74. Li, Q.; Ma, Y.; Li, L.; Bao, J.; Zhang, L. Flagellin influences the expression of a variety of important cytokines and chemokines without affecting the immune status of umbilical cord mesenchymal stem cells. Mol. Med. Rep. 2015, 12, 6955-6961. [CrossRef] [PubMed]

75. Sato, B.L.; Collier, E.S.; Vermudez, S.A.; Junker, A.D.; Kendal-Wright, C.E. Human amnion mesenchymal cells are proinflammatory when activated by the Toll-like receptor 2/6 ligand, macrophage-activating lipoprotein-2. Placenta 2016, 44, 69-79. [CrossRef]

76. Yang, Y.; Wang, Y.; Li, L.; Chen, F.; Zhang, P. Activation of the Toll-like receptor 8 pathway increases the immunogenicity of mesenchymal stem cells from umbilical cord. Mol. Med. Rep. 2017, 16, 2061-2068. [CrossRef]

77. Najar, M.; Martel-Pelletier, J.; Pelletier, J.P.; Fahmi, H. Mesenchymal Stromal Cell Immunology for Efficient and Safe Treatment of Osteoarthritis. Front. Cell Dev. Biol. 2020, 8, 567813. [CrossRef] [PubMed]

78. Szklarczyk, D.; Gable, A.L.; Lyon, D.; Junge, A.; Wyder, S.; Huerta-Cepas, J.; Simonovic, M.; Doncheva, N.T.; Morris, J.H.; Bork, P.; et al. STRING v11: Protein-protein association networks with increased coverage, supporting functional discovery in genome-wide experimental datasets. Nucleic Acids Res. 2019, 47, D607-D613. [CrossRef]

79. Colemonts-Vroninks, H.; Neuckermans, J.; Marcelis, L.; Claes, P.; Branson, S.; Casimir, G.; Goyens, P.; Martens, G.A.; Vanhaecke, T.; De Kock, J. Oxidative Stress, Glutathione Metabolism, and Liver Regeneration Pathways Are Activated in Hereditary Tyrosinemia Type 1 Mice upon Short-Term Nitisinone Discontinuation. Genes 2020, 12, 3. [CrossRef] 
80. Bolleyn, J.; Rombaut, M.; Nair, N.; Branson, S.; Heymans, A.; Chuah, M.; Vanden Driessche, T.; Rogiers, V.; De Kock, J.; Vanhaecke, T. Genetic and Epigenetic Modification of Rat Liver Progenitor Cells via HNF4 $\alpha$ Transduction and 5' Azacytidine Treatment: An Integrated miRNA and mRNA Expression Profile Analysis. Genes 2020, 11, 486. [CrossRef]

81. Buyl, K.; Vanhaecke, T.; Desmae, T.; Lagneaux, L.; Rogiers, V.; Najar, M.; De Kock, J. Evaluation of a new standardized enzymatic isolation protocol for human umbilical cord-derived stem cells. Toxicol. Vitro 2015, 29, 1254-1262. [CrossRef] [PubMed] 